\title{
Bacteriophages and Their Derivatives as Biotherapeutic Agents in Disease Prevention and Treatment
}

\author{
Mohamed Elbreki, ${ }^{1}$ R. Paul Ross, ${ }^{2,3}$ Colin Hill, ${ }^{3,4}$ Jim O'Mahony, \\ Olivia McAuliffe, ${ }^{2}$ and Aidan Coffey ${ }^{1}$ \\ ${ }^{1}$ Department of Biological Sciences, Cork Institute of Technology, Bishopstown, Cork, Ireland \\ ${ }^{2}$ Biotechnology Department, Teagasc, Moorepark Food Research Centre, Fermoy, Co. Cork, Ireland \\ ${ }^{3}$ Alimentary Pharmabiotic Centre, University College, Cork, Ireland \\ ${ }^{4}$ Department of Microbiology, University College, Cork, Ireland
}

Correspondence should be addressed to Aidan Coffey; aidan.coffey@cit.ie

Received 25 October 2013; Accepted 4 December 2013; Published 26 March 2014

Academic Editor: Yves Mely

Copyright (C) 2014 Mohamed Elbreki et al. This is an open access article distributed under the Creative Commons Attribution License, which permits unrestricted use, distribution, and reproduction in any medium, provided the original work is properly cited.

\begin{abstract}
The application of bacteriophages for the elimination of pathogenic bacteria has received significantly increased attention worldwide in the past decade. This is borne out by the increasing prevalence of bacteriophage-specific conferences highlighting significant and diverse advances in the exploitation of bacteriophages. While bacteriophage therapy has been associated with the Former Soviet Union historically, since the 1990s, it has been widely and enthusiastically adopted as a research topic in Western countries. This has been justified by the increasing prevalence of antibiotic resistance in many prominent human pathogenic bacteria. Discussion of the therapeutic aspects of bacteriophages in this review will include the uses of whole phages as antibacterials and will also describe studies on the applications of purified phage-derived peptidoglycan hydrolases, which do not have the constraint of limited bacterial host-range often observed with whole phages.
\end{abstract}

\section{Bacteriophage History}

Bacteriophages (phages) were first characterised about 100 years ago by [1-3]. Earlier authors, such as Ernest Hankin [4], Nikolay Gamaleya [5], and Frederick Twort [6], are understood to have observed the antibacterial activity of phages without being able to recognise or identify the agents responsible. Nowadays, most recognition for the development of phage therapy goes to Felix d'Herelle who isolated these agents from the stool samples of dysentery patients, named them bacteriophages, and developed the phage assays which remain in use up to the present $[7,8]$. He also initiated the first phage therapy experiments in the early 1920s. Research in phage therapy was eclipsed in the West by the advent and increasing widespread successful application of antibiotics in medical practice from the late 1940s. Phage therapy, on the other hand, was declined largely due to variable and unpredictable results, an issue related to the relatively poor understanding of phage biology at the time. Certainly, many of the illnesses that had been treated with phage preparations up to the mid-twentieth century were likely to have not had a bacterial basis. Thus, the results of phage therapy generally tended to be inferior to those observed for antibiotics, since the latter had a broader therapeutic spectrum and, generally, did not require detailed bacteriological knowledge for effective prescribing by practitioners. The use of phages to treat bacterial infections has recently gained attention in Western medicine mainly due to ever-increasing incidence of bacterial resistance to antibiotics and also due to the fact that phage biology, phage-bacteria interaction, and the basis for bacterial infections are vastly better understood than was the case in the mid-twentieth century when phage therapy was eclipsed by antibiotic treatments [7].

\section{Sources of Bacteriophages}

Phages are found in almost all environments on Earth, ranging from soil, sediments, water (both river and seawater), and in/on living or dead plants/animals. Essentially, phages 


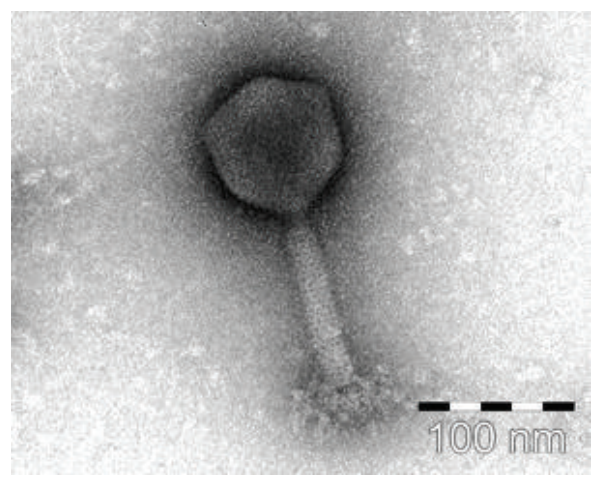

(a)

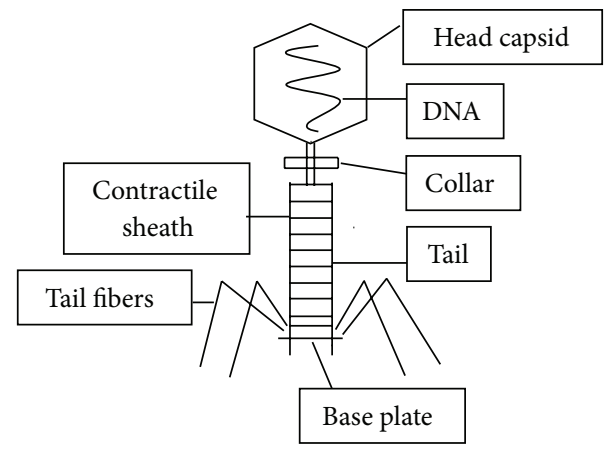

(b)

FIGURE 1: Electron micrograph of a negatively stained Acinetobacter baumannii phage (a) and generalised structure of a tailed phage (b).

can be isolated from almost any material that will support bacterial growth. The estimated global phage population size is extraordinarily high. For instance, it is estimated that aquatic environments have a total phage population above $10^{31}[9,10]$. Many terrestrial ecosystems have been shown to harbour $10^{7}$ phages per gram of soil; and sewage is known to contain in the range of $10^{8}-10^{10}$ phage per millilitre [11-15].

\section{Classification of Bacteriophages}

Phages have evolved an array of shapes, sizes, capsid symmetries, and structures. All are composed of nucleic acid (genome) encapsulated by a protein coat (capsid). Phage genomes can be double- or single-stranded DNA or doubleor single-stranded RNA. Capsids have been identified in many forms, ranging from small 3D hexagon-like structures to filaments to highly complex structures consisting of a head and a tail (Figure 1). It is estimated that approximately 5,500 bacteriophages have been viewed by electron microscopy since 1959. Of those studied from a morphological perspective, $96.3 \%$ had a tailed morphology $[16,17]$. Over the years, a sophisticated phage classification system has been drawn up by the International Committee for Taxonomy of Viruses (ICTV) to account for the diversity. Originally the taxonomy of phages was organised according to their morphological characteristics, type of nucleic acid, and presence or absence of envelope or lipid. According to this approach, phages were organised into 14 distinct phage families as shown in Figure 2 [18-20]. More recently, the importance of phage genome sequences comparisons has also been recognised. Some of the phage families have been grouped into orders; for example, the three-tailed phage families (Figure 2) (Myoviridae, Siphoviridae, and Podoviridae) belong to the Caudoviralesorder, and the Archaea-infecting Lipothrixviridae and Rudiviridae phages belong to the Ligamenvirales order.It is noteworthy that many of the other families have not yet been assigned an order. The inoviruses (Inoviridae family) consist of a nonenveloped rod of protein filaments surrounding a circular, ssDNA genome. The microviruses (Microviridae family) possess a linear, ssDNA genome and a nonenveloped,

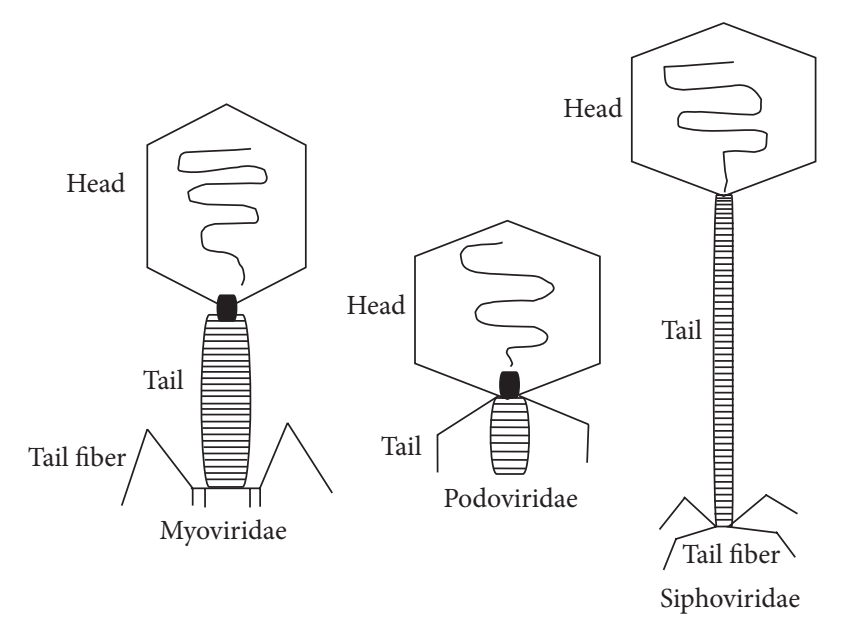

Figure 2: The three-tailed phage families (Myoviridae, Siphoviridae and Podoviridae).

icosahedral capsid. The tectiviruses (Tectiviridae family) and corticoviruses (Corticoviridae family) both possess external icosahedral capsids with a lipid membrane lying directly beneath. These two families differ in terms of capsid and genome organisation. Whereas the corticovirus genome is circular and highly supercoiled, the tectivirus genome is linear with terminal inverted repeats. By contrast, the plasmaviruses (Plasmaviridae family) possess an external lipid envelope, pleomorphic geometry, and a circular genome. They are only known to infect the mycoplasmal genus Acholeplasma. The cystoviruses (Cystoviridae family) have a linear, segmented, dsRNA genome. They are charactarised by a double capsid with a surrounding lipid envelope. The leviviruses (Leviviridae family) have a linear, positivestranded, ssRNA genome and a nonenveloped, spherical capsid (Table 1; Figure 3).

\section{Bacteriophage Life Cycles}

A common characteristic of phages is that, although their genome carries the information required to drive their own 

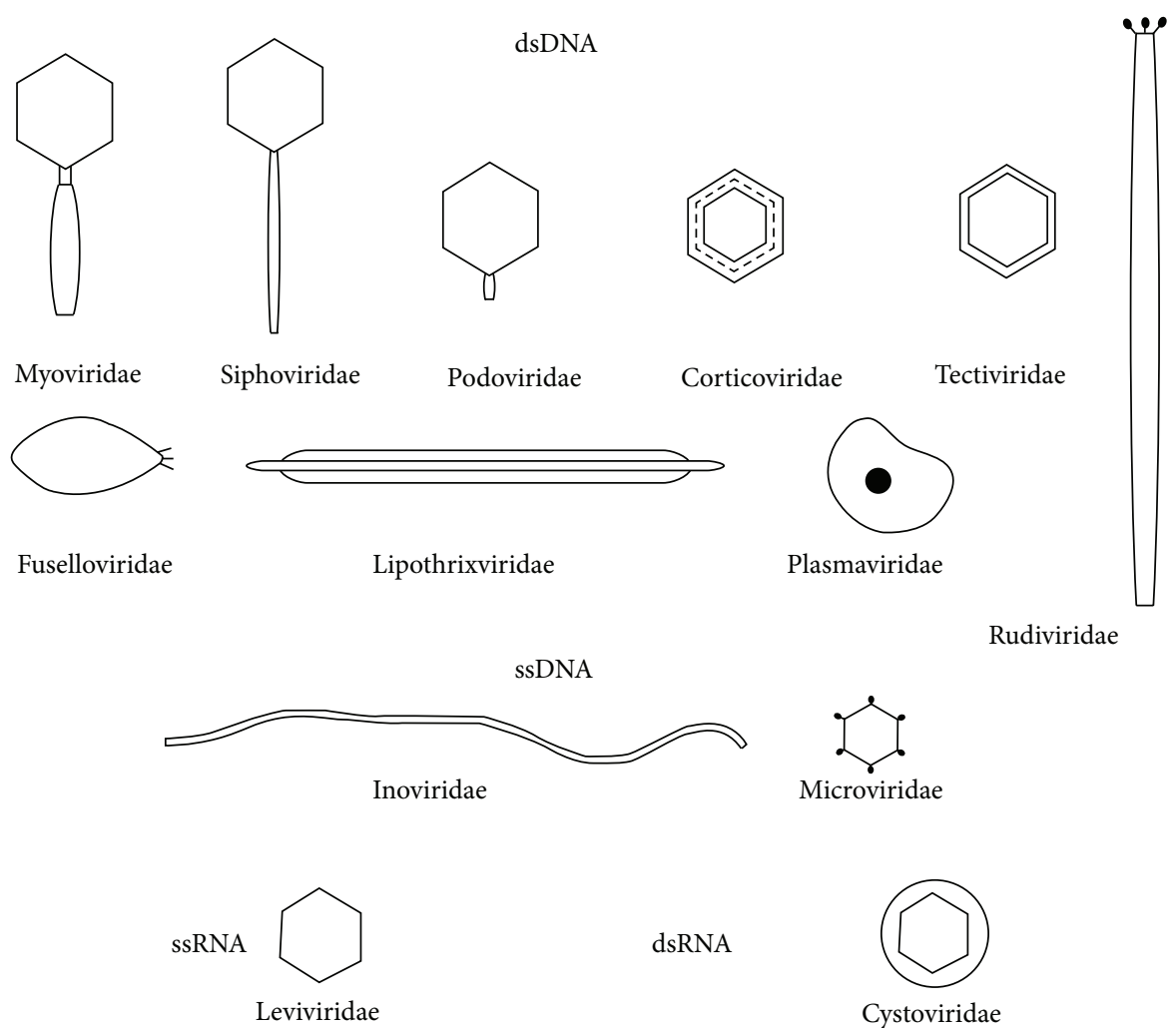

dsRNA

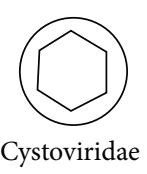

FIGURE 3: The fourteen phage families based on morphology and genome characteristics. See Table 1 for further details.

multiplication, they completely rely on the energy and protein biosynthetic machinery of their bacterial hosts to complete their lytic cycle, rendering them obligatory intracellular parasites of bacteria $[8,10,21]$. The first contact between a phage and its host happens by random collision, provided that the cell carries specific receptors on its surface. The contact is usually made between the receptor molecules of the host (e.g., teichoic acid in Gram-positives or lipopolysaccharide in Gram-negatives) and specific phage proteins located at the tip of the tail fibre, or at one end of a filamentous phage. Injection of DNA follows immediately after a phage has stably and irreversibly adsorbed to the cell surface [22]. Based on their subsequent propagation cycle, most phages can be broadly divided into two major groups: virulent and temperate (Figure 4). Virulent phages immediately redirect the host metabolism toward the production of new phage virions, which are released upon cell death within several minutes to hours after the initial phage attachment event. This is termed the lytic cycle. Virulent phage infection results in clear plaques on the respective host bacterial lawns. Temperate phages can replicate either by the lytic cycle as described above or by establishing a stable long-term viable relationship with their host bacteria. In this state, the phage DNA is replicated together with the host's chromosome. This is termed the lysogenic cycle, during which viral genes that are detrimental to the host are not expressed $[8,13,20,23,24]$.

\section{Bacterial Resistance to Phages}

Bacteria can evolve resistance to phages. These resistance mechanisms are manifested when an interruption occurs during phage development, through specific molecular mechanisms, which have evolved in bacteria throughout their coevolution with phages. Bacteria are able to defend against phage infection almost in every stage of the infection process. By blocking phage receptors, producing an extracellular matrix and competitive inhibitors, bacteria prevent the phage from adsorbing to their surface. This is termed phage adsorption inhibition. Injection of the phage genome can also be inhibited through a process known as injection blocking [25]. Phage inhibition can also occur after phage genome injection into a host as a result of bacterial-encoded endonucleases that recognise and destroy foreign DNA, a phenomenon known as restriction-modification. Bacterial protection of its own DNA is based on modification by methylation at specific points on its DNA sequence, which concomitantly will give protection against restriction endonuclease cleavage. Restriction results in the cleavage of foreign DNA that does not carry the corresponding methylation pattern. Some unmodified phage genomes physically avoid host-mediated restriction (possibly by encountering the methylase enzyme molecule in advance of meeting the endonuclease), and, on being replicated, their genome becomes modified. This enables resulting phage to evade restriction by a particular 
TABLE 1: The fourteen phage families based on morphology and genome characteristics.

\begin{tabular}{lll}
\hline Family & Morphology & Nucleic acid \\
\hline Myoviridae & Nonenveloped, contractile tail & Linear dsDNA \\
Siphoviridae & Nonenveloped, noncontractile tail (long) & Linear dsDNA \\
Podoviridae & Nonenveloped, noncontractile tail (short) & Linear dsDNA \\
Lipothrixviridae & Enveloped, rod-shaped (infect Archea) & Linear dsDNA \\
Rudiviridae & Nonenveloped, rod-shaped (infect Archea) & Linear dsDNA \\
Ampullaviridae & Enveloped, bottle-shaped & Linear dsDNA \\
Bicaudaviridae & Nonenveloped, lemon-shaped & Circular dsDNA \\
Clavaviridae & Nonenveloped, rod-shaped & Circular dsDNA \\
Corticoviridae & Nonenveloped, isometric & Circular dsDNA \\
Cystoviridae & Enveloped, spherical & Segmented dsRNA \\
Fuselloviridae & Nonenveloped, lemon-shaped & Circular dsDNA \\
Globuloviridae & Enveloped, isometric & Linear dsDNA \\
Guttavirus & Nonenveloped, ovoid & Circular dsDNA \\
Inoviridae & Nonenveloped, filamentous & Circular ssDNA \\
Leviviridae & Nonenveloped, isometric & Linear ssRNA \\
Microviridae & Nonenveloped, isometric & Circular ssDNA \\
Plasmaviridae & Enveloped, pleomorphic & Circular dsDNA \\
Tectiviridae & Nonenveloped, isometric & Linear dsDNA \\
\hline
\end{tabular}

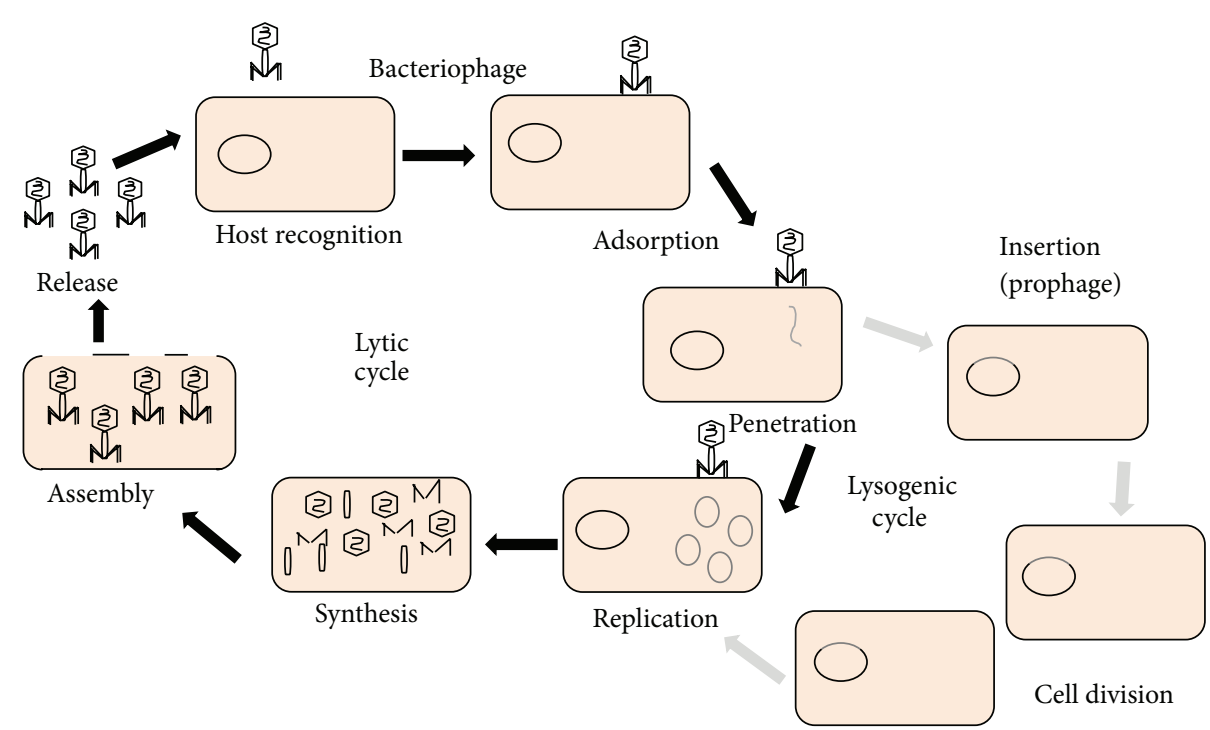

FIGURE 4: The steps during the bacteriophage lytic and lysogenic life cycles. The well-known bacteriophage Lambda has a choice between both cycles. Some phages are exclusively virulent, never entering the lytic cycle. Others are long-term residents of the bacterial host chromosome and in some cases may have lost the ability to excise and enter the lytic cycle.

host restriction/modification system in subsequent infective cycles [26-28]. Another mechanism of phage resistance termed abortive infection represents a broad range of diverse phage resistance mechanisms whereby the phageinfected cells often die before completing the lytic cycle, thus containing the virus and preventing it from proliferating. Abortive infection mechanisms frequently have a different primary function in bacteria [25]. CRISPRs (clustered regularly interspaced short palindromic repeats) are loci containing multiple, short direct repeats, which are found in the genomes of approximately $40 \%$ of sequenced bacteria and $90 \%$ of sequenced Archaea [29]. CRISPRs function like a prokaryotic immune system in that they confer a form of acquired immunity to exogenous genetic elements such as plasmids and phages. Short segments of foreign DNA, called spacers, are incorporated into the genome between CRISPR repeats and serve as a "memory" of past exposures. CRISPR spacers are then used to recognise and silence exogenous genetic elements in a manner analogous to RNA in eukaryotic organisms $[25,30,31]$. The mechanism of CRISPR/Cas interference involves three phases (Figure 5). 


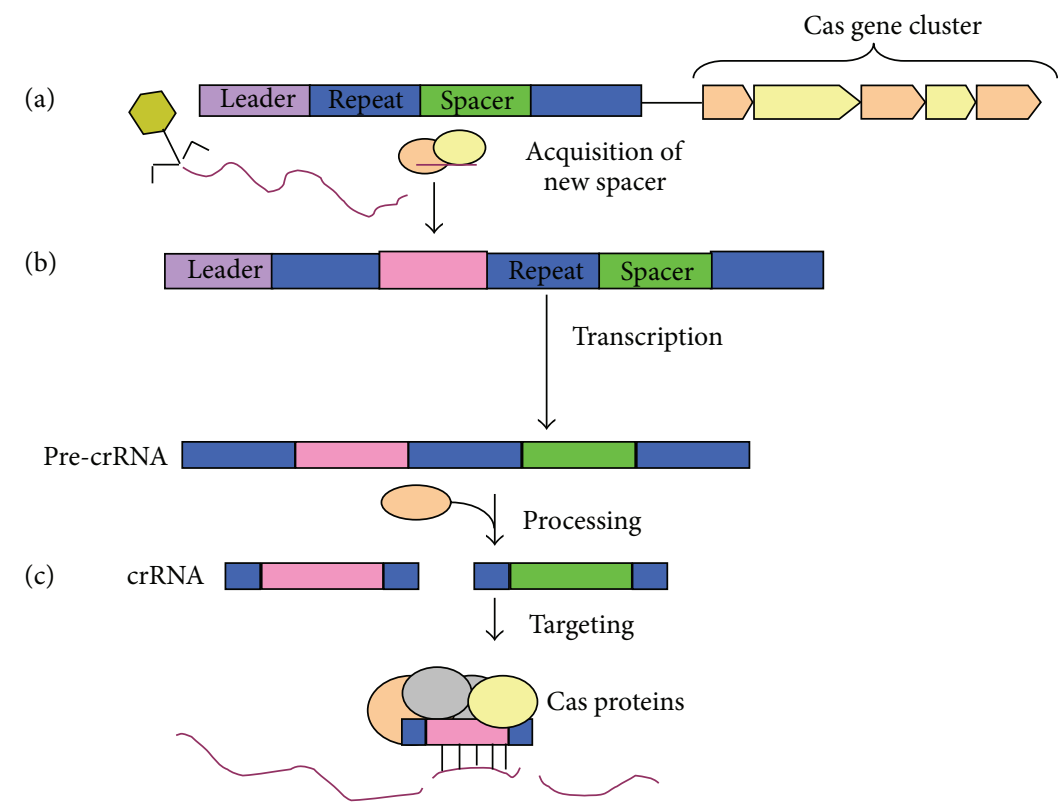

FIGURE 5: Overview of clustered regularly interspaced short palindromic repeats (CRISPR)/CRISPR associated (Cas) adaptive immunity. (a) Adaptation. The CRISPR arrays are composed of short repeats and intervening sequences derived from foreign invaders. Upon infection with a foreign element (e.g., phages), part of the genome is typically incorporated into the leader end of the CRISPR array and the repeat is duplicated. The CRISPR arrays are located adjacent to a cluster of Cas genes. (b) crRNA generation. The CRISPRs are transcribed into pre-crRNAs that are then processed into mature crRNAs. (c) Interference. The crRNA, in a complex with Cas proteins, binds and degrades the target nucleic acid of the invading element.

Firstly, resistance is acquired via the integration of short sequences from foreign genetic elements (termed spacers) into repetitive genetic elements known as CRISPR arrays. Secondly, CRISPR arrays are then transcribed and processed into small RNAs (crRNAs) by Cas proteins. In the third and final step, targeting of the invading phage or plasmid is mediated by a Cas protein complex that contains crRNAs. During this stage, the crRNA-Cas protein complex then interferes, in a sequence-specific manner, with the foreign nucleic acids [32].

\section{Significance of Bacteriophages}

6.1. Ecological Importance of Bacteriophages. Phages are more numerous than any other organism in the biosphere, prokaryotes included, and are found in all ecosystems on Earth. There is considerable evidence of the significant role that phages play in prokaryotic evolution in terms of gene transfer by transduction and also in terms of controlling bacterial populations in specific niches. The concentration of phages in natural waters indicates that phage infection may be an important factor in recycling of nutrients as a result of prokaryotic cell lysis and thus influence levels of planktonic microorganisms [33]. For example Hankin in 1896 investigated the difference between the cholera outbreaks along the Ganges and Jumna Rivers in India; Hankin found an unknown source of antibacterial activity against $V$. cholerae in the river and then suggested that this unidentified substance, which passed through fine porcelain filters and was heat labile, was responsible for limiting the spread of cholera epidemics [4]. At the same time, an interesting relationship between $V$. cholerae and vibriophages in the environment was also reported and suggested that the cessation of cholera epidemic was due to the spread of bacteriophages from convalescent cases [34]. It is also noted that significant quantities of phages are also found in soil and in the gut of animals where they are likely to have similar roles [35].

6.2. Economic Importance of Bacteriophages. In the dairy industries, many different lactic acid bacteria are used as starter cultures in the production of products such as cheese and yoghurt. Infections of starter cultures by lytic phages can lead to the slowing or arrest of fermentations and subsequent loss of production. Thus, phages of lactic acid bacteria are a real threat to the milk fermentation industry because of (a) its global magnitude and (b) the fact that in a typical factory, there is multiple filling of vats providing ample opportunities for phages to propagate to high numbers in a single day's production, which may typically see many vats of several thousand litres filled repeatedly with milk each day $[36,37]$. The fact that the substrate is a nonsterile liquid facilitates easier dissemination of phage particles. Thus, a typical observation in a cheese factory might be to see the starter culture "phaging out" after 15 vats of the planned 40 , resulting in reduced product output by the industry. Such a detrimental economic impact has resulted in major investment in phage-resistant starter culture research and the genetic improvement of industrial starter strains of lactic acid bacteria [25]. In the area of food safety, phages also are becoming very important. Since 2006, phages have been 
approved for the elimination of Listeria monocytogenes in food products [38]. A study using phage for biocontrol of Salmonella on both cooked and raw beef found significant reductions when samples were incubated at both refrigeration and room temperature conditions [39], and this application is likely to expand in the future.

6.3. Medical and Therapeutic Application of Bacteriophages. The first use of phages as therapeutic agents in humans started in 1919, shortly after their discovery (Figure 6), when they were successfully used to treat severe cases of bacterial dysentery in four children in Paris, France. All of the treated children recovered from what otherwise could have been a fatal infection. The study was conducted in close collaboration with Felix d'Herelle, one of the discoverers of phages. Shortly afterwards, in 1921, Richard Bruynoghe and Joseph Maisin used phages to treat a staphylococcal skin disease [40]. Despite this promising beginning in the preantibiotic era, the success of early phage therapy was short-lived [41, 42]. This was due to a variety of factors that included (1) a lack of understanding of phage biology, (2) poor experimental techniques, (3) poor quality of phage preparations, (4) a lack of understanding of the underlying causes of ailment being treated, and (5) ultimately the discovery and ease of use of antibiotics. The first evidence of the nature of phage only became available in 1936 when Schlesinger reported the composition of phage particles being $50 \%$ protein and $50 \%$ nucleic acid and later with the first electron microscopic observation of phages [43, 44]. Thus, the application of phages as therapeutic agents was heavily compromised. As a result, phage therapy and its associated research were abandoned in Western countries, but they continued in Poland and in countries within the Former Soviet Union (FSU). For example, the Bacteriophage Institute in Tbilisi (now the George Eliava Institute of Bacteriophage, Microbiology and Virology) is still researching phage therapy applications and supplies phage for the treatment of various bacterial infections $[8,10,42,45]$.

The increasing prevalence of antibiotic resistance and multidrug-resistance in bacterial pathogens led the Western scientific community to reassess the potential applications of phages and phage products in the treatment of certain infectious diseases [44, 46-48], such as Pseudomonas spp. [49], vancomycin-resistant Enterococci [5052], antibiotic-resistant Staphylococci [53, 54], multidrugresistant Klebsiella pneumonia [55], imipenem-resistant [56, 57] and multidrug-resistant Pseudomonas aeruginosa [58, 59], antibiotic-resistant strains of Escherichia coli [60], and methicillin-resistant Staphylococcus aureus [61]. Today, there are several different antibacterial strategies derived from phages including enzybiotics (cloned host-specific, phageencoded lytic enzymes introduced to combat bacteria without the whole phage) and whole-phage therapy (introducing whole, viable phage to attack the infecting bacteria) $[8,62-$ 64]. Typically, whole-phage preparations may contain one or a small number of phage strains, each with a broad range of activity within a bacterial genus; or, alternatively, phage may be applied as a mixture of several phages, which as a mixture has activity against a broad range of strains/species
[2]. This approach with whole phages is largely based on the phage preparations used throughout the Former Soviet Union (FSU). Available data suggest that the use of phages as antibacterial agents is rather simple and has many advantages over antibiotics $[8,19,53,54,65]$. These advantages may be summarised as follows: (1) phages are specific and, therefore, cannot eliminate ecologically important bacteria (e.g., gut microflora); (2) phages cease to function soon after all their specific target host bacterial cells are destroyed and, hence, will disperse harmlessly; (3) human patients who are allergic to antibiotics can be treated with phages with no side effects; (4) phages are safe to use because they have no effect on mammalian cells; (5) phages can be administered in various routes-for example, topically, intravenous, or orally; (6) phages reproduce exponentially; hence, a single dose can be sufficient to treat an infection; (7) when resistant bacterial strains arise in the host, the phage has capabilities to overcome this resistance by mutating in step with the evolving bacteria; (8) production of phages is simple and inexpensive; (9) phages are ubiquitous and, thus, regarded as safe.

There are, however, still some disadvantages that must be considered when using phage therapy: (1) phage specificity implies that the causative bacterial pathogens have to be identified by the medical practitioner prior to phage administration, and, also, the lytic spectrum of the phage may be limited to only one subtype of bacterial pathogen; (2) low or no efficacy has been reported in certain cases, but this may be attributed to either incorrect diagnosis of the disease or insufficient phage dose, together with an ineffective phage delivery approach; (3) phage administration requires a neutralised environment, which, for example, is generally not found in the digestive system of animals due to the presence of gastric secretions $[12,21,66]$.

In comparing the advantages and disadvantages, phages do certainly have several characteristics that confer on them strong potential as therapeutic agents. In addition, the large and ever-increasing number of publications shows that the scientific and technical understanding of phage therapy is constantly improving, and given the increasing need for nonantibiotic therapies, it is likely that phage therapy will become a reality in the near future.

6.4. Recent Research in the Use of Phages as Antimicrobial Agents. The last decade has brought several substantial developments in phage therapy, which is currently leading to greater interest in Western medicine as an alternative to antibiotics in the treatment of infections caused by multidrug-resistant bacteria [67]. The recent increase in interest began to a large extent with a Polish study first reported in 1985 in which phages were applied in 114 cases of suppurative bacterial infections in children followed by scientific analysis. Positive therapeutic results were obtained in 109 (95.6\%) cases; patients had a wide range of bacterial infections caused by the pathogenic Staphylococci, Klebsiella, Escherichia, Proteus, and Pseudomonas bacteria [68]. In a follow-up to this study, phage preparations were administered to patients in various age groups with a wide range of antibiotic-resistant infections caused by the aforementioned 


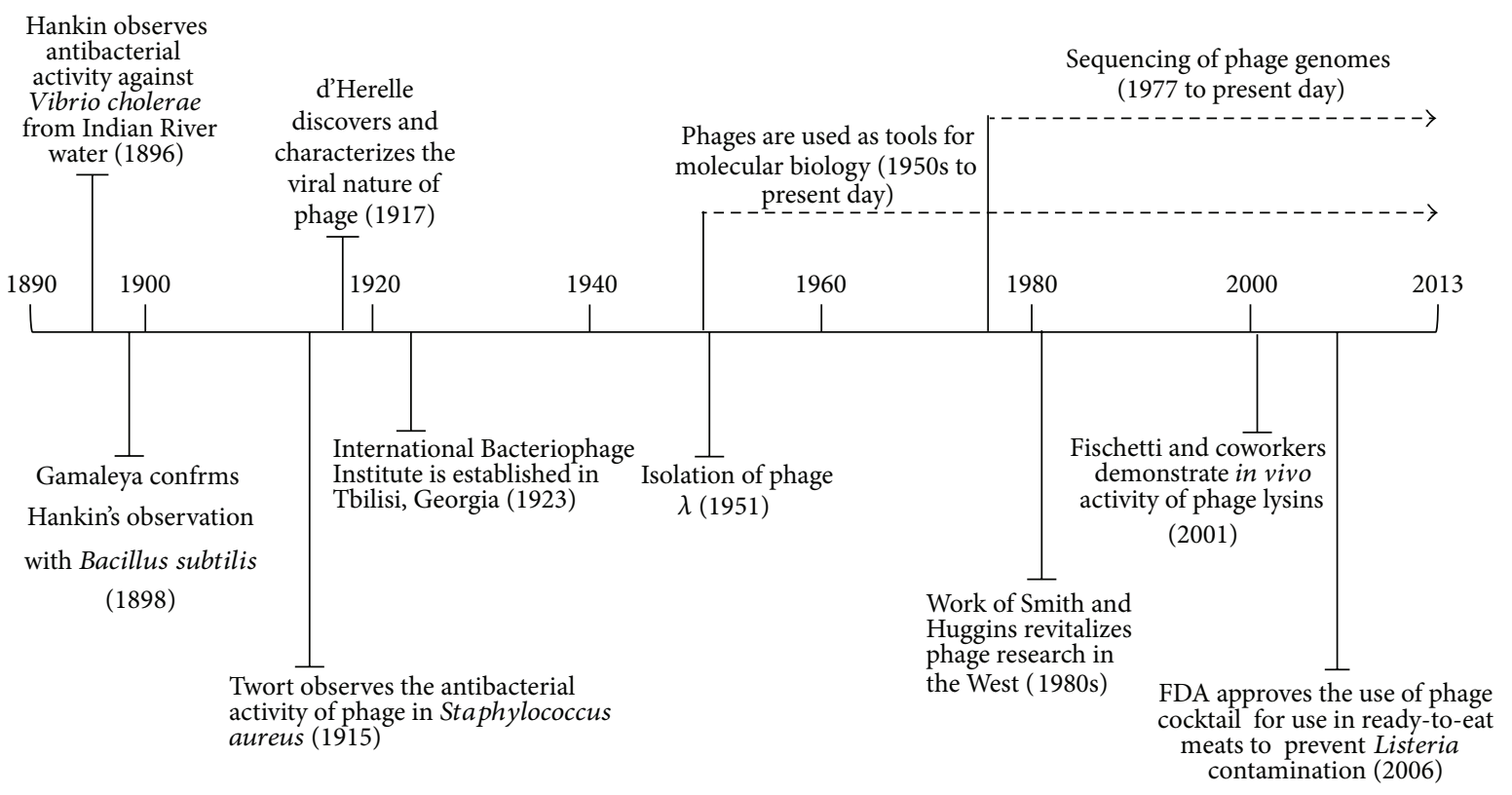

FIGURE 6: Timeline of major milestones in phage history.

pathogens. The patient ages ranged from one week to 86 years of age. The phages were administered orally three times per day, locally by direct application on wounds, or by dropping a phage suspension into the eye, ear, or nose. In most cases, bacterial sensitivity to the phage was monitored and different phages were applied in situations where phage resistance had occurred. In one report from this study, the results from 550 cases were reported from 1981 to 1986 . These results showed that over $92 \%$ of patients were cured, and about $6.9 \%$ of patients showed an improvement in condition in contrast to only $0.7 \%$ of the cases of patients where the phage therapy proved to be ineffective [23,69]. Another suppurative chronic skin infection study by the same group used phage to treat the infections in 31 patients ranging in age from 12 to 86 years old, whose infections were caused by Pseudomonas, Staphylococcus, Klebsiella, Proteus, and E. coli. Of the 31 cases, $77 \%$ showed improvements in condition [70]. Later, the same group reported a broader study with a larger number of patients and obtained similar results [71]. These infections included suppurative wound infections, gastroenteritis, sepsis, osteomyelitis, dermatitis, empyemas, and pneumonia: and again, pathogens included Staphylococcus, Streptococcus, Klebsiella, Escherichia, Proteus, Pseudomonas, Shigella, and Salmonella spp. More recently in the same group, antibioticresistant septicaemia was treated with phage therapy in 94 patients. In 71 of these cases, antibiotic treatment was continued in conjunction with phage therapy and in the remaining 23 cases phage alone was administered. Of the 94 cases, complete recovery was achieved in $85.1 \%$ of cases, whereas in $14.9 \%$ of cases phage therapy was ineffective [47]. The Polish scientists reported a success rate of 80$95 \%[72,73]$, which applied to the older studies in which phage preparations were produced by the institute and distributed to local hospitals and individual patients. It is noteworthy that most patients, some of them with acute rather than chronic infections, were not directly monitored by the institute staff. Therefore, not all data reported could be directly verified. In 2005, the phage therapy centre was established at the institute, which is responsible for direct patient care, supervision, and monitoring according to the current standards of the EU and FDA under the Declaration of Helsinki. Only patients with antibiotic-resistant infections have been accepted and the published results suggest notable success rates of approximately $40 \%$ for this group of patients in whom all available therapy had failed [74]. The results have been supported by a more recent but similar British study, which also demonstrated significant efficacy of phages against Escherichia coli, Acinetobacter spp., Pseudomonas spp., and Staphylococcus aureus [75]. In this case, phage therapies in a group of 1,307 patients ranging in age from 4 weeks to 86 years from 1987 to 1999 were investigated. Full recovery occurred in $85.9 \%$ of cases, and an improvement in condition occured in $10.9 \%$ of cases, while no improvement was observed in $3.8 \%$ of cases. As with the earlier study, patients had a wide range of bacterial infections caused by the pathogens Staphylococcus, Klebsiella, Escherichia, Enterobacter, Proteus, and Pseudomonas. Similar important work with similar findings was performed at the Eliava Institute for Bacteriophage, Microbiology and Virology in Tbilisi, Georgia, and the details have been reviewed by Sulakvelidze and Kutter [44]. A Swiss group led by Brussow performed a safety test on phage administration in human volunteers. In this study, 15 healthy adult volunteers received T4 coliphage in their drinking water, at a concentration up to $10^{5} \mathrm{PFU} / \mathrm{mL}$. No adverse effects identified in volunteers receiving phage T4 [76]. Also Sarker et al. gave a 9-phage cocktail to 15 healthy adult volunteers. The phages were detected in $64 \%$ of the stool samples when subjects were treated with higher titer phage, compared to $30 \%$ and $28 \%$ when treated with lower-titer phage. No Escherichia coli was present in initial 
stool samples, and no amplification of phage was observed. One percent of the administered oral phage was recovered from the feces. No adverse events were observed by selfreport, clinical examination, or from laboratory tests for liver, kidney, and hematology function. In addition, no impact was seen on the fecal microbiota composition with respect to bacterial 16S rRNA from stool [77].

\section{Phages Therapy in Animal Models of Human Infection}

Notwithstanding the above promising human studies, several animal models have also been conducted in keeping with the normal process in new drug or anti-infective development studies. These models have allowed for the evaluation and comparison of the different possible administration routes, timings, and dose-titres of phage. The use of animals as models for microbiological infections has been a fundamental part of infectious disease research, and many research groups have also applied this to phage and their studies are summarised in Table 2. The study of Smith and Huggins 1982 mentioned that a single intramuscular dose of one anti-K1 phage was more effective than multiple intramuscular doses of tetracycline, ampicillin, chloramphenicol, or trimethoprim plus sulphafurazole in curing mice of a potentially lethal intramuscularly or intracerebrally induced infection of Escherichia coli strain; it was at least as effective as multiple intramuscular doses of streptomycin. A notable study by Biswas et al. [50] used the virulent phage ENB6 from raw sewage, and its activity was tested against a wide range of clinical isolates of vancomycinresistant Enterococcus faecium (VRE). The study reports that the induction of a bacteremia in mice with a high dose of VRE $\left(10^{9} \mathrm{CFU}\right)$ and an incubation time of $45 \mathrm{~h}$ after injection can be fully cured by a single intraperitoneal (i.p.) injection dose of $3 \times 10^{8}$ PFU of phage ENB6. Another recent interesting use of phage therapy showed the efficacy of the lytic phage 9882 isolated from hospital sewage in overcoming virulent beta-lactamase- (ESBL-) producing E. coli strains. Notably, this study examined the timing of administration of the therapeutic phage and showed that it is of major importance for the total elimination of infectious bacteria. For example, the efficacy of the activity of the phage varied up to $100 \%$ if the phage was introduced 40 min after the bacterial infection to $60 \%$ if the phage was introduced $60 \mathrm{~min}$ after infection. This study also showed that therapeutic efficacy was directly linked to the functional capability of the phage and not to any other immunological reaction of the host that may be thought to have been triggered by the physical introduction of the phage [56]. These researchers used the same strategy to examine the effectiveness of phages in the treatment of imipenem-resistant Pseudomonas aeruginosa (IMPR-Pa). The phage (isolated from hospital sewage and designated phage A392) was shown to have in vitro lytic activity against a wide range of clinical isolates of IMPR-Pa. The phage was shown to overcome a high-dose, systemic bacterial infection as well as wound infection in mice. Thus, the study demonstrated that the therapeutic efficacy of the phages was independent of the administration routes, but overall, the timing of administration is very important [57]. Another study focused on the details of multiplicity of infection (MOI) of phage against multidrug-resistant uropathogenic E. coli (UPEC). Phage T4 and a newly isolated phage (KEP10) were injected at an MOI of 60 in mice that were administrated with a UPEC strain. After seven days, 100 and $90 \%$ of mice treated with T4 and KEP10, respectively, had survived. In the control group, where no phages were administered, all the mice died within three days [78]. In addition, lower multiplicities of infection (0.03 and 0.003$)$ resulted in a reduced rescue of animals (60 and 40\%) [79].

An intraperitoneal phage administration study involving phage SS specific for K. pneumoniae was conducted to treat mice that had been challenged by intranasal inoculation with $K$. pneumoniae $\left(10^{8} \mathrm{CFU} / \mathrm{mL}\right)$. A single intraperitoneal injection of $10^{10} \mathrm{CFU} / \mathrm{mL}$ phage SS administered immediately after intranasal inoculation challenge was sufficient to rescue $100 \%$ of animals from the $K$. pneumoniae-mediated respiratory infections [80]. In addition, in a rabbit model of wound infection, abscess formation in rabbits was prevented when $2 \times 10^{9}$ PFU of phage LS2a was injected simultaneously with $8 \times 10^{7} \mathrm{CFU}$ of $S$. aureus into the same subcutaneous site [81]. The studies reported above were performed under different conditions but demonstrate that the experimental conditions for phage therapy are dependent on the specific infection being treated. Furthermore, these studies illustrate the importance of timing of phage administration, MOI, and route of phage administration in some cases. In addition, phages can have enhanced therapeutic efficacy when they are (i) virulent for the corresponding bacterial host, (ii) essentially free of contaminating bacterial toxin, and (iii) capable of evading the reticuloendothelial system (RES). A notable study by Merril et al. [65] identified phages that were selected for their ability to survive longer than control phage in the blood of mice. The development of such phage may provide important tools for the treatment of bacterial diseases. Therefore, before phages are administered to humans and animals for treatment, (especially for new phages) animal models are an important initial step to help determine potential experimental conditions down the line, such as route and timing of administration and MOI.

\section{Use of Phage to Eliminate Biofilms}

Biofilm formation is an important bacterial survival strategy, particularly on surfaces. Biofilms are microbial structures consisting of microbial cells surrounded by an exopolymeric matrix. In humans, biofilms are responsible for many pathologies, including those associated with the use of medical devices [82]. Since the first phage/biofilm study was reported in 1995 [83], there has been an increased interest in using phage to eliminate biofilms (Table 3 ). This is due to the ability of phages in general to replicate at the site of an infection and in some cases to produce enzymes that degrade the extracellular polymeric substance matrix of a biofilm [84]. Significantly, the development of extracellular polysaccharide-based matrices by biofilm bacteria does not 
TABLE 2: Use of bacteriophages to control pathogenic bacteria in animal models of human infection.

\begin{tabular}{|c|c|c|c|c|}
\hline Infection hosts & Bacteria & Phage & Main outcome & Reference \\
\hline Mice & E. coli & Anti-K1 & $\begin{array}{l}\text { Better mice survival rates with } \\
\text { phage }\end{array}$ & Smith and Huggins, 1982 [119] \\
\hline $\mathrm{BALB} / \mathrm{c}$ mice & Klebsiella & $\begin{array}{l}\text { Klebsiella pneumoniae } \\
\text { bacteriophage }\end{array}$ & $\begin{array}{l}\text { Rescue of generalized Klebsiella } \\
\text { infection }\end{array}$ & Bogovazova et al., 1991 [120] \\
\hline Guinea pigs & P. aeruginosa & BS24 & $\begin{array}{l}\text { Skin graft protection from bacteria } \\
\text { by phage }\end{array}$ & Soothill, 1994 [75] \\
\hline Mice & E. coli, S. typhimurium & $\lambda$ and P22 & $\begin{array}{l}\text { Identification, isolation, and } \\
\text { subsequent use of long circulating } \\
\text { phage }\end{array}$ & Merril et al., 1996 [65] \\
\hline Chickens and calves & $\begin{array}{l}\text { E. coli } H 247 \\
(\mathrm{O} 18: K 1: H 7)\end{array}$ & $\Phi \mathrm{R}$ & $\begin{array}{l}\text { Protection against morbidity and } \\
\text { mortality }\end{array}$ & Barrow et al., 1998 [121] \\
\hline Hamsters & C. difficile & CD140 & $\begin{array}{l}5 / 6 \text { hamster survived in the } \\
\text { phage-treated group compared with } \\
\text { none in the control }\end{array}$ & Rdamesh, 1999 [122] \\
\hline $\mathrm{BALB} / \mathrm{c}$ mice & Helicobacter pylori & M13 & $\begin{array}{l}\text { Reduction of stomach colonization } \\
\text { by Helicobacter }\end{array}$ & Cao et al., 2000 [123] \\
\hline Mice & E. faecium & ENB6 & $\begin{array}{l}100 \% \text { survival } 45 \text { min after phage } \\
\text { administration }\end{array}$ & Biswas et al., 2002 [50] \\
\hline Mice & V. vulnificus & $\begin{array}{l}\text { CK-2, 153A-5, and } \\
153 \mathrm{~A}-7\end{array}$ & $\begin{array}{l}\text { Different results of mice protection } \\
\text { depending on the phage used. CK-2 } \\
\text { and 153A- } 5 \text { protected mice, whereas } \\
\text { 153A-7 did not }\end{array}$ & Cerveny et al., 2002 [124] \\
\hline Mice & E. coli & LW and LH & $\begin{array}{l}\text { Mortality rates in mice varied } \\
\text { depending on the phage used }\end{array}$ & Bull et al., 2002 [125] \\
\hline Mice & S. aureus & MR11 & $\begin{array}{l}\text { Better mouse survival rates with } \\
\text { phage administration (MOI40.1) } \\
\text { straight after bacterial } \\
\text { administration }\end{array}$ & Matsuzaki et al., 2003 [126] \\
\hline Chicken skin & $\begin{array}{l}\text { Salmonella enterica and } \\
\text { Campylobacter jejuni }\end{array}$ & P125589 and P22 & $\begin{array}{l}\text { Reduction by } 2 \log \text { units in bacterial } \\
\text { abundance over } 48 \text { hours }\end{array}$ & Goode et al., 2003 [127] \\
\hline $\mathrm{BALB} / \mathrm{c}$ mice & Pseudomonas aeruginosa & Phage Pf3R & $\begin{array}{l}\text { Higher survival rate and reduced } \\
\text { inflammatory response after } 12-24 \\
\text { hours }\end{array}$ & Hagens et al., 2004 [128] \\
\hline Rabbits & S. aureus & LS2a & $\begin{array}{l}\text { Reduction in abscess size in } \\
\text { phage-treated animals and no } \\
\text { difference when phage } \\
\text { administration was delayed }\end{array}$ & Wills et al., 2005 [81] \\
\hline Mice & $\begin{array}{l}\text { E. coli } \\
\mathrm{O} 157: \mathrm{H} 7\end{array}$ & SP15, SP21, and SP22 & $\begin{array}{l}\text { Successive daily phage } \\
\text { administration was required to } \\
\text { reduce cell numbers from the } \\
\text { gastrointestinal tract }\end{array}$ & Tanji et al., 2005 [129] \\
\hline Chicken & Salmonella enteritidis & $\begin{array}{l}\text { CNPSA 1, CNPSA } 3 \text {, } \\
\text { and CNPSA } 4\end{array}$ & $\begin{array}{l}\text { Reduction of Salmonella enteritidis } \\
\text { counts in treated chicken cuts }\end{array}$ & Fiorentin et al., 2005 [130] \\
\hline Chicken & $\begin{array}{l}\text { Salmonella } \\
\text { typhimurium }\end{array}$ & $\begin{array}{l}\text { Salmonella-specific } \\
\text { phages }\end{array}$ & $\begin{array}{l}\text { Reduction in Salmonella counts in } \\
\text { cecum and ileum treated chickens }\end{array}$ & Toro et al., 2005 [131] \\
\hline Mice & P. aeruginosa & A392 & $\begin{array}{l}100 \% \text { survival rate } 60 \text { min after } \\
\text { phage administration. Reduced } \\
\text { survival rates when phages were } \\
\text { administrated at } 180 \text { and } 360 \text { min }\end{array}$ & Wang et al., 2006b [57] \\
\hline Mice & E. coli & 9882 & $\begin{array}{l}100 \% \text { survival at } 24-168 \mathrm{~h} \text { after } \\
\text { phage administration }(40 \mathrm{~min} \text { after } \\
\text { bacterial administration) }\end{array}$ & Wang et al., 2006a [56] \\
\hline Shrimp & Vibrio harveyi & Siphoviridae & Improved larval survival & Vinod et al., 2006 [132] \\
\hline Mice & P. aeruginosa & Pal, Pa2, and Pa11 & $\begin{array}{l}87 \% \text { protection against bacterial } \\
\text { infection in mouse burn model } \\
\text { compared with } 6 \% \text { in the untreated } \\
\text { group after intraperitoneal injection }\end{array}$ & McVay et al., 2007 [133] \\
\hline
\end{tabular}


TABLe 2: Continued.

\begin{tabular}{|c|c|c|c|c|}
\hline Infection hosts & Bacteria & Phage & Main outcome & Reference \\
\hline Mice & P. aeruginosa & KPP10 & $\begin{array}{l}\text { Survival rates of } 66.7 \% \text { for the } \\
\text { phage-treated group versus } 0 \% \text { for } \\
\text { the saline-treated control group }\end{array}$ & Watanabe et al., 2007 [134] \\
\hline Mice & E. coli & T4 and KEP10 & $\begin{array}{l}100 \% \text { survival rate with T4. } 90 \% \\
\text { survival rate with KEP10 }\end{array}$ & Nishikawa et al., 2008 [78] \\
\hline Mice & E. faecalis & $\mathrm{EF} 24 \mathrm{C}$ & $\begin{array}{l}100 \% \text { survival rate with a phage } \\
\text { MOI of } 0.1\end{array}$ & Uchiyama et al., 2008 [51] \\
\hline Mice & P. aeruginosa & CSV-31 & $\begin{array}{l}100 \% \text { protection observed when } \\
\text { phage was administrated } 45 \mathrm{~min} \\
\text { after bacterial challenge }\end{array}$ & Vinodkumar et al., 2008 [58] \\
\hline Mice & K. pneumonia & SS & $\begin{array}{l}\text { Immediate administration of phage } \\
\text { resulted in } 100 \% \text { protection; this } \\
\text { decreased after } 3 \mathrm{~h} \text { and no } \\
\text { protection at } 6 \mathrm{~h} \text { was observed after } \\
\text { bacterial challenge }\end{array}$ & Chhibber et al., 2008 [80] \\
\hline Mice & K. pneumoniae & Kpn5 & $\begin{array}{l}\text { Phage was able to rescue mice from } \\
\text { infection caused by K. pneumoniae }\end{array}$ & Kumari et al., 2010 [135] \\
\hline Mice & P. aeruginosa & PA1 & $\begin{array}{l}\text { No viable bacteria were found in } \\
\text { organ samples after } 48 \mathrm{~h} \text { of the } \\
\text { phage treatment }\end{array}$ & Tiwari et al., 2011 [136] \\
\hline Mice & P. aeruginosa & NH-4 and MR299-2 & $\begin{array}{l}\text { Killing the pathogen in the lungs of } \\
\text { infected mice after phage mixture } \\
\text { administration }\end{array}$ & Alemayehu et al., 2012 [137] \\
\hline Mice & E. coli & $\mathrm{EC} 200(\mathrm{PP})$ & $\begin{array}{l}100 \% \text { survival mice } 1 \text { and } 7 \mathrm{~h} \text { after } \\
\text { phage administration }\end{array}$ & Pouillot et al., 2012 [138] \\
\hline
\end{tabular}

protect cells from lysis by bacteriophage [85]. Phages evidently penetrate the extracellular biofilm matrix that binds macromolecules and cells to eliminate their target bacterial cells [86].

\section{Phage Endolysins as Therapeutics}

Many phages encode specific peptidoglycan-degrading enzymes, also known as murein hydrolases or endolysins (lysins), which are responsible for lysis of the host bacterial cell at the end of the lytic cycle. To achieve access to the cell wall, endolysins require a second lysis factor-a small membrane protein designated a holin, which permits penetration of the plasma membrane [87-91]. Both endolysin and holin proteins are produced in the late stage of the lytic cycle, when they accumulate in the cytosol of the host cell. At a genetically specific time, holin protein forms pores in the plasma membrane, thus, providing access for the endolysin to reach its target in the peptidoglycan where it will cause rapid cell lysis with the concomitant release of mature phage progeny (Figure 7) $[92,93]$. Many endolysins studies to date display a two- or three-domain modular structure [94, 95] with an N-terminal catalytic domain(s) and a C-terminal cell wall-binding domain [96-99] (Figure 7(b)). Lysins are classified into five different groups depending on their cleavage site within the peptidoglycan. These are (1) N-acetyl$\beta$-D-muramidase (lysozymes); (2) lytic transglycosylase; (3) $\mathrm{N}$-acetyl- $\beta$-D-glucosaminidases (glycosidases), which hydrolyse the $\beta-1-4$ glycosidic bond in the sugar moiety of the cell wall; (4) N-acetylmuramoyl-L-alanine amidases, which cleave the amide bond connecting the sugar and peptide moieties of the bacterial cell wall, and (5) L-alanoyl-Dglutamate endopeptidases and interpeptide bridge-specific endopeptidases, which attack the peptide moiety of the cell wall peptidoglycan (Figure 8) [96, 100-102]. If purified and applied exogenously, endolysins are only effective against Gram-positive bacteria; the outer membrane of Gramnegatives prevents access of exogenous Gram-negative endolysins [103].

Lysins have recently received considerable attention in the context of exploitation as novel antibacterials, and their potential has been extensively reviewed [24, 100, 104].

A variety of in vitro tests and animal models using different purified preparations of lysins, either alone, in combination, or together with classical antibiotics, have demonstrated the potential of many phage lysins as therapeutics or biocontrol agents, and those that have been well researched are summarised in Tables 4(a) and 4(b).

The pioneer of endolysin antibacterial research is undoubtedly Vincent Fischetti, whose group showed that the streptococcal lysin encoded by phage $\mathrm{Cl}$ is specific for groups A, C, and E Streptococci $[105,106]$. The addition of $1,000 \mathrm{U}$ of purified lysin in vitro within five seconds resulted in $100 \%$ inhibition of $10^{7} \mathrm{CFU} / \mathrm{mL}$ of group A Streptococci. Furthermore, in a mouse model of infection, protection of mice from group A Streptococci colonisation was evident. In this case, a single dose of lysin $(250 \mathrm{U})$ was added to 
TABLE 3: Phages and bacterial hosts used in biofilm eradication studies.

\begin{tabular}{|c|c|c|c|}
\hline Year & Bacteria & Phage & Reference \\
\hline 1995 & E. coli & $\mathrm{T} 4$ & Doolittle et al., 1995 [83] \\
\hline 1996 & E. coli, $P$. aeruginosa & T4, E79 & Doolittle et al., 1996 [139] \\
\hline 1998 & E. agglomerans & 53b SF153b & Hughes et al., 1998 [140] \\
\hline 2001 & E. coli & $\mathrm{K}-12 \mathrm{~T} 4$ & Corbin et al., $2001[141]$ \\
\hline 2004 & P. fluorescens & $\varphi \mathrm{S} 1$ & Sillankorva et al., 2004 [142] \\
\hline 2005 & E. coli & O157 : H7 KH1 & Sharma et al., 2005 [143] \\
\hline 2008 & P. fluorescens & $\varphi \mathrm{S} 1$ & Sillankorva et al., 2008 [144] \\
\hline 2010 & K. pneumoniae & KPO1K2 & Verma et al., 2010 [145] \\
\hline 2010 & L. monocytogenes & P100 & Soni and Nannapaneni, 2010 [146] \\
\hline 2011 & S. aureus & SAP-26 & Rahman et al., 2011 [147] \\
\hline 2011 & P. aeruginosa & PAO1 and ATCC 10145 & Pires et al., 2011 [148] \\
\hline 2012 & P. aeruginosa & $\varphi \mathrm{MR} 299-2$ and $\varphi \mathrm{NH}-4$ & Alemayehu et al., 2012 [137] \\
\hline 2012 & E. coli & $\begin{array}{l}\text { vB_EcoP_ACG-C91, } \\
\text { vB_EcoM_ACG-C40, } \\
\text { vB_EcoS_ACG-M12 }\end{array}$ & Chibeu et al., 2012 [149] \\
\hline 2012 & S. aureus & $\mathrm{K}$ & Kelly et al., 2012 [85] \\
\hline 2012 & A. baumannii & AB7-IBB1 & Yele et al., 2012 [150] \\
\hline 2012 & A. baumannii & AB7-IBB2 & Thawal et al., 2012 [151] \\
\hline
\end{tabular}

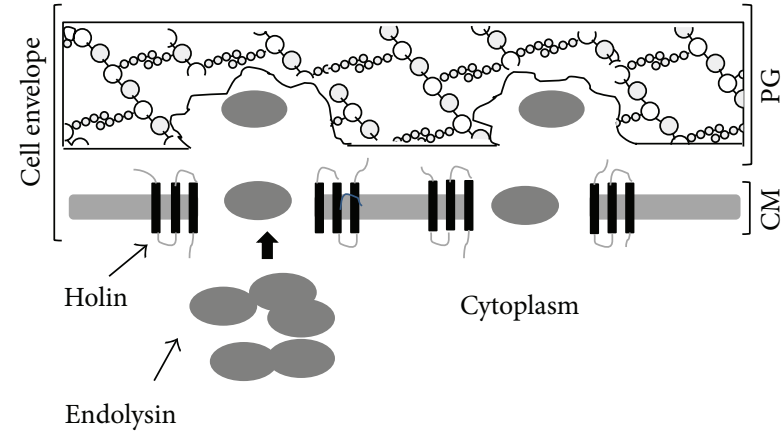

(a)

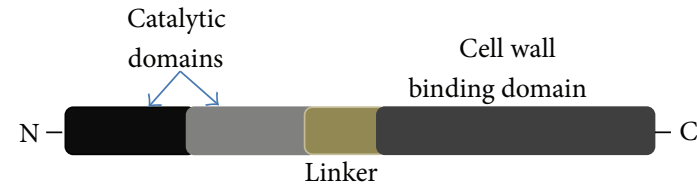

(b)

FiguRE 7: Schematic representation of the modular structure (a) and mode of action (b) of phage-encoded endolysins. Most endolysins are characterised by one or two catalytic domains and one cell wall-binding domain involved in substrate recognition. Access of the endolysin to the peptidoglycan (PG) layer is often aided by insertion of the holin into the cytoplasmic membrane (CM).

the oral cavity of mice before the addition of $10^{7} \mathrm{CFU} / \mathrm{mL}$ of group A Streptococci. Indeed, in an additional experiment following administration of lysin $(500 \mathrm{U})$ to mice that were heavily colonised with group A Streptococci, no Streptococci were detected $2 \mathrm{~h}$ after treatment [106]. The same research group also studied the Streptococcus pneumoniae phage lysin enzyme (Pal) and demonstrated that it was able to eradicate 15 common serotypes of Pneumococci [105]. It has clearly been shown that the use of purified Cpl-1 and/or Pal 1 lysins was very efficient in curing heavy infections caused by $S$. pneumoniae strain $6 \mathrm{~B}$ and the acute otitis caused by S. pneumoniae [107, 108]. Fischetti's group also focused on a Bacillus anthracis phage lysin and showed that it could be exploited for the detection and elimination of this pathogen, which has associations with bioterrorism. In this case, the lysin was identified from phage $\gamma$ of $B$. anthracis and was found to be effective against vegetative cells as well as germinating spores. The lysins tested were PlG and PlyPH. The latter is especially resistant to a wide $\mathrm{pH}$ range $[109,110]$. Other lysins were also shown to have a great deal of lytic activity against streptococci; however, it is noteworthy that LySMP manifested a prominent lytic activity that is greater than that seen with the whole phage [111-113].

Staphylococcal phage MR11 was originally reported to be active against Staphylococcus infections in mice. Its lysin was subsequently cloned and designated MV-L lysin and used to eliminate MRSA in the nasal cavities of mice. Complete elimination of bacteria was observed in one of nine mice treated with MV-L lysin. The remaining mice had much lower $\mathrm{CFU} /$ nasal cavity numbers than the untreated controls. In an additional experiment with a model of systemic MRSA disease after 60 days, all mice treated with MV-L lysin directly 
TABLE 4: Phage lysins targeting pathogenic bacteria.

\begin{tabular}{|c|c|c|c|c|}
\hline Bacteria & Phage & Lysins & Activity & References \\
\hline S. pneumoniae & Cp1 & Cpl-1 & Muramidase & $\begin{array}{l}\text { Loeffler et al., } 2001 \text { [105]; Jado et al. } \\
2003 \text { [107]; McCullers et al., } 2007 \\
{[108]}\end{array}$ \\
\hline S. pneumoniae & Dp-1 & Pal & Amidase & Jado et al., 2003 [107] \\
\hline S. pyogenes & $\mathrm{C} 1$ & $\mathrm{C} 1$ & Amidase & Nelson et al., 2001 [106] \\
\hline B. anthracis & $\gamma$ & PlyG & Amidase & Schuch et al., 2002 [109] \\
\hline B. anthracis & Ames prophage & PlyPH & Amidase & Yoong et al., 2006 [110] \\
\hline $\begin{array}{l}\text { E. faecalis and } \\
\text { E. faecium }\end{array}$ & Phil & PlyV12 & Amidase & Yoong et al., 2004 [114] \\
\hline S. aureus & MR11 & MV-L & Endopeptidase and amidase & Rashel et al., 2007 [99] \\
\hline S. pyogenes & $\mathrm{C} 1$ & PlyC & Amidase & Hoopes et al., 2009 [152] \\
\hline S. agalactiae & B30 & GBS lysin & Muramidase and endopeptidase & Pritchard et al., 2004 [153] \\
\hline S. aureus & P68 & Lys16 & Endopeptidase & Takáč et al., 2005 [154] \\
\hline S. aureus & $\mathrm{K}$ & LysK & Amidase and endopeptidase & O'Flaherty et al., 2005 [53] \\
\hline S. aureus & MR11 & MV-L & Amidase and endopeptidase & Rashel et al., 2007 [99] \\
\hline L. monocytogenes & A118 & Ply118 & Amidase & Gaeng et al., 2000 [155] \\
\hline L. monocytogenes & A511 & Ply511 & Amidase & Gaeng et al., 2000 [155] \\
\hline L. monocytogenes & A500 & Ply500 & Endopeptidase & Loessner et al., 2002 [91] \\
\hline S. pneumoniae & $\Phi D p-1$ & Pal, S & Amidase and endopeptidase & Loeffler et al., 2001 [105] \\
\hline S. agalactiae & $\begin{array}{l}\text { LambdaSal } \\
\text { prophage }\end{array}$ & $\begin{array}{l}\text { LambdaSal } \\
\text { prophage lysin }\end{array}$ & Glycosidase & Pritchard et al., 2007 [156] \\
\hline S. agalactiae & $\begin{array}{l}\text { LambdaSa2 } \\
\text { prophage }\end{array}$ & $\begin{array}{l}\text { LambdaSa2 } \\
\text { prophage lysin }\end{array}$ & Glycosidase and endopeptidase & Pritchard et al., 2007 [156] \\
\hline S. uberis & $\begin{array}{l}\text { (ATCC700407) } \\
\text { prophage }\end{array}$ & Ply700 & Amidase & Celia et al., 2008 [111] \\
\hline S. suis & SMP & LySMP & Glycosidase and endopeptidase & Wang et al., 2009 [113] \\
\hline B. anthracis & Bcp1 & PlyB, & Muramidase & Porter et al., 2007 [157] \\
\hline S. aureus & Phill and Phil2 & Phill lysin & Amidase and endopeptidase & Sass and Bierbaum, 2007 [158] \\
\hline S. aureus & ФMR11 & MV-L & Amidase and endopeptidase & Rashel et al., 2007 [99] \\
\hline S. aureus & $\Phi \mathrm{H} 5$ & LysH5 & Amidase and endopeptidase & Obeso et al., 2008 [112] \\
\hline S. warneri & ФWMY & LysWMY & Amidase and endopeptidase & Yokoi et al., 2005 [159] \\
\hline Streptococci (GBS) & ФNCTC 11261 & PlyGBS & Muramidase and endopeptidase & Cheng et al., 2005 [160] \\
\hline C. perfringens & Ф3626 & Ply3626 & Amidase & Zimmer et al., 2002 [115] \\
\hline C. difficile & ФCD27 & CD27 lysin & Amidase & Mayer et al., 2008 [161] \\
\hline E. faecalis & $\Phi 1$ & PlyV12 & Amidase & Yoong et al., 2004 [114] \\
\hline A. naeslundii & $\Phi A v-1-$ & Av-1 lysin & $\begin{array}{l}\text { Putative amidase/ } \\
\text { muramidase }\end{array}$ & Delisle et al., 2006 [162] \\
\hline L. gasseri & $\Phi g a Y$ & LysgaY & Muramidase & Sugahara et al., 2007 [163] \\
\hline S. aureus & ФSA4 & LysSA4 & Amidase and endopeptidase & Mishra et al., 2013 [164] \\
\hline S. haemolyticus & ФSH2 & $\mathrm{SH} 2$ & Amidase and endopeptidase & Schmelcher et al., 2012 [165] \\
\hline B. thuringiensis & ФBtCS33 & PlyBt33 & Amidase & Yuan et al., 2012 [166] \\
\hline L. monocytogenes & ФР40 & PlyP40 & Amidase & Eugster and Loessner, 2012 [167] \\
\hline L. monocytogenes & ФFWLLm3 & LysZ5 & Amidase & Zhang et al., 2012 [168] \\
\hline B. cereus & ФBPS13 & LysBPS13 & Amidase & Park et al., 2012 [169] \\
\hline S. aureus & ФGH15 & LysGH15 & Amidase and endopeptidase & Gu et al., $2011[170]$ \\
\hline S. aureus & ФvB_SauS-PLA88 & HydH5 & Endopeptidase and glycosidase & Rodríguez et al., 2011 [171] \\
\hline E. faecalis & $\Phi F 168 / 08$ & Lys168 & Endopeptidase & Proença et al., 2012 [172] \\
\hline E. faecalis & $\Phi F 170 / 08$ & Lys170 & Amidase & Proença et al., 2012 [172] \\
\hline
\end{tabular}


TABLE 4: Continued.

\begin{tabular}{|c|c|c|c|c|}
\hline Bacteria & Phage & Lysins & Activity & References \\
\hline S. aureus & ФР-27/HP & $\mathrm{P}-27 / \mathrm{HP}$ & Nonspecified & Gupta and Prasad, 2011 [173] \\
\hline C. perfringens & ФSM101 & Psm & Muramidase & Nariya et al., 2011 [174] \\
\hline C. sporogenes & $\Phi 8074-\mathrm{B} 1$ & CS74L & Amidase & Mayer et al., 2012 [175] \\
\hline S. typhimurium & ФSPN1S & Lysin SPN1S & Glycosidase & Lim et al., 2012 [176] \\
\hline C. michiganensis & ФСМР1 & CMP1 & Peptidase & Wittmann et al., 2010 [177] \\
\hline C. michiganensis & ФCN77 & CN77 & Peptidase & Wittmann et al., 2010 [177] \\
\hline A. baumannii & ФАВ2 & LysAB2 & Glycosidase & Lai et al., $2011[178]$ \\
\hline B. cereus & ФВ4 & LysB4 & Endopeptidase & Son et al., 2012 [179] \\
\hline P. aeruginosa & $\Phi K M V$ & KMV45 & Nonspecified & Briers et al., 2011 [117] \\
\hline C. tyrobutyricum & ФСТР1 & Ctpll & Glycosidase & Mayer et al., 2010 [180] \\
\hline P. aeruginosa & $\Phi E L$ & EL188 & Transglycosylase & Briers et al., 2007 [181] \\
\hline P. aeruginosa & $\Phi K Z$ & KZ144 & Transglycosylase & Briers et al., 2007 [181] \\
\hline S. aureus & & Ply187 & Nonspecified & Mao et al., 2013 [182] \\
\hline P. fluorescens & ФОВР & OBPgp279 & Glycosidase & Walmagh et al., 2012 [116] \\
\hline L. monocytogenes & ФР35 & PlyP35 & Amidase & Eugster et al., 2011 [183] \\
\hline L. fermentum & ФРҮВ5 & Lyb5 & Muramidase & Hu et al., $2010[184]$ \\
\hline S. pneumoniae & ФСР-7 & Cpl-7 & Muramidase & Bustamante et al., 2010 [185] \\
\hline P. chlororaphis 201 & $\Phi 2-1$ & $201 \varphi 2-\operatorname{lgp} 229$ & Glycosidase & Walmagh et al., 2012 [116] \\
\hline S. enterica & ФPVP-SE1) & PVP-SE1gp146 & Glycosidase & Walmagh et al., 2012 [116] \\
\hline Corynebacterium & ФВFК20 & BFK20 & Amidase & Gerova et al., 2011 [186] \\
\hline E. faecalis & ФEFAP-1 & EFAL-1 & Amidase & Son et al., 2010 [187] \\
\hline Lactobacilli & lamdaSA2 & $\begin{array}{l}\text { Lys A, LysA2, and } \\
\text { LysgaY }\end{array}$ & Nonspecified & Roach et al., 2013 [188] \\
\hline S. aureus & & SAL-1 & Nonspecified & Jun et al., 2013 [189] \\
\hline
\end{tabular}

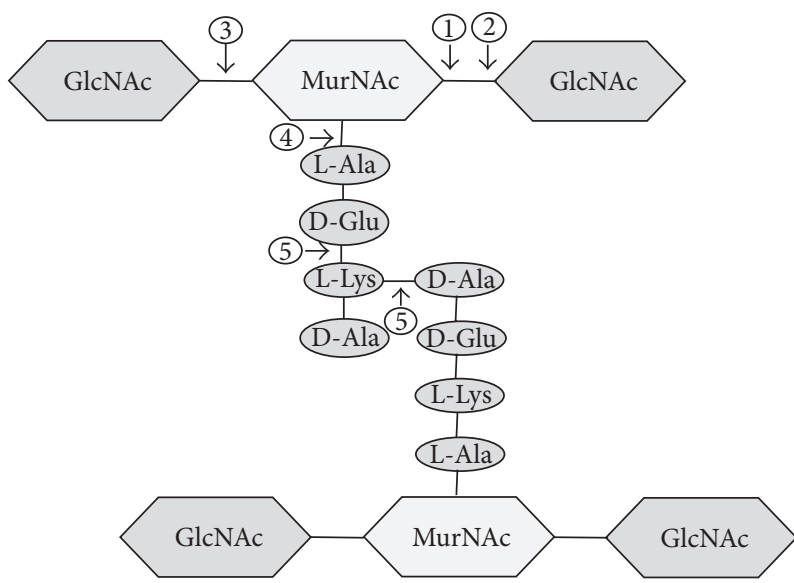

FIGURE 8: Typical peptidoglycan structure of Gram-positive bacteria, showing lysin cleavage sites. The cleavage sites are indicated: (1) N-acetyl- $\beta$-D-muramidase (lysozymes), (2) lytic transglycosylase, (3) N-acetyl- $\beta$-D-glucosaminidase, (4) N-acetylmuramoyl-Lalanine amidases, and (5) endopeptidase. Abbreviations: GlcNAc (N-acetyl glucosamine), MurNAc (N-acetyl muramic acid).

or 30 min after bacterial administration survived compared with $60 \%$ survival 60 min after bacterial administration [99]. In the genus Enterococcus, the lysin PlyV12 was found to have activity not only against its host $E$. faecalis but also against other Gram-positive pathogens, such as Staphylococci and Streptococci. In this case, the authors suggested that this might be due to a common surface structure between these pathogens [114].

The use of lysins is not limited to animal models of infection and the control of infection caused by virulent bacteria. Their use was recently extended to the area of food safety. This is illustrated by the use of the lysin Ply3626 that is active against $C$. perfringens [115], really third most common cause of food-borne illness. Investigations in the area of Gram-negative endolysins as antibacterial applications have also been undertaken, for example, in the case of Pseudomonas aeruginosa. While such endolysins (unlike those of Gram-positives) generally have a broad target range among Gram-negative genera, their application as antibacterials is compromised by the presence of the outer membrane. Thus, antibacterial activity has only been shown to be possible after treatment of the outer membrane of Gram-negative cells with EDTA [116] or by the fusion of hydrophobic amino acids to the endolysin, which enables the movement of the endolysin across the outer membrane. The latter approach has been recently developed in endolysins by the group of Lavigne in Belgium [117] and was based on earlier observations where the action of lysozyme against $E$. coli was enhanced by the fusion of a hydrophobic pentapeptide onto 
the C-terminus [118]. The advantage of the use of lysins over other antibacterials (or antibiotics) is their specificity for one bacterial pathogen without disturbing other nonpathogenic bacterial flora. There is also a very low chance of bacterial resistance to endolysins, due to the fact that resistance would necessitate an alteration in fundamental peptidoglycan structure. To date no lysin-resistant bacteria have been identified. Thus, lysins could be effective antibacterials in an age of increasing antibiotic resistance. It is worthy of mention that one potential concern in the use of lysins is the development of lysin-neutralising antibodies. Unlike antibiotics, which are small molecules that are generally not immunogenic, endolysins are proteins that stimulate an immune response when delivered both mucosally and systemically. Despite the limited studies on endolysin immunogenicity, it has been reported that highly immune serum slows, but does not block the killing of bacteria by lysins $[87,88,114]$.

\section{Conclusions}

The continued, world-wide antibiotic resistance problem requires the exploitation of inexpensive, natural, available, safe, and efficient therapeutic agents. Consequently, investigations of phage confirmed that they can be specific and highly effective in lysing targeted pathogenic bacteria. The safety of such therapies has been demonstrated by their wide clinical use in Eastern Europe and the Former Soviet Union. Phages are stable and easy to purify at a relatively low cost. They are naturally widespread in many environments on Earth and play an important role in bacterial ecology and evolution. Therefore, investigations of the use of phage for the elimination of pathogenic bacteria are well justified and from the cases discussed here it is clear that use of phages or their lytic enzymes has a considerable array of applications as therapeutics in the modern medical and veterinary fields.

\section{Conflict of Interests}

The authors declare no conflict of interests.

\section{References}

[1] F. d'Hérelle, "Sur un microbe invisible antagoniste des bacilles dysentériques," Comptes Rendus de l'Académie des SciencesSeries D, vol. 165, pp. 373-375, 1917.

[2] D. H. Duckworth, “Who discovered bacteriophage?"” Bacteriological Reviews, vol. 40, no. 4, pp. 793-802, 1976.

[3] M. Mattey and J. Spencer, "Bacteriophage therapy-cooked goose or Phoenix rising?" Current Opinion in Biotechnology, vol. 19, no. 6, pp. 608-612, 2008.

[4] E. H. Hankin, "Laction bactéricide des eaux de la Jumna et du Gange sur le vibrion du cholera," Annales de l'Institut Pasteur, vol. 10, pp. 511-523, 1896.

[5] N. F. Gamaleya, "Bacteriolysins-ferments destroying bacteria," Russian Archives of Pathology, Clinical Medicine, and Bacteriology, vol. 6, pp. 607-613, 1898.

[6] F. W. Twort, "An investigation on the nature of ultramicroscopic viruses," The Lancet, vol. 186, no. 4814, pp. 1241-1243, 1915.
[7] A. Sulakvelidze, Z. Alavidze, and J. G. Morris Jr., "Bacteriophage therapy," Antimicrobial Agents and Chemotherapy, vol. 45, no. 3, pp. 649-659, 2001.

[8] W. C. Summers, "Bacteriophage therapy," Annual Review of Microbiology, vol. 55, pp. 437-451, 2001.

[9] M. L. Pedulla, M. E. Ford, J. M. Houtz et al., "Origins of highly mosaic mycobacteriophage genomes," Cell, vol. 113, no. 2, pp. 171-182, 2003.

[10] A. Parisien, B. Allain, J. Zhang, R. Mandeville, and C. Q. Lan, "Novel alternatives to antibiotics: bacteriophages, bacterial cell wall hydrolases, and antimicrobial peptides," Journal of Applied Microbiology, vol. 104, no. 1, pp. 1-13, 2008.

[11] A. Dublanchet and S. Bourne, "The epic of phage therapy," Canadian Journal of Infectious Diseases and Medical Microbiology, vol. 18, no. 1, pp. 15-18, 2007.

[12] B. Guttman, R. Raya, and E. Kutter, "Basic phage biology," in Bacteriophages: Biology and Applications, pp. 29-63, CRC Press, 2005.

[13] E. Strauch, J. A. Hammerl, and S. Hertwig, "Bacteriophages: new tools for safer food?" Journal fur Verbraucherschutz und Lebensmittelsicherheit, vol. 2, no. 2, pp. 138-143, 2007.

[14] D. L. Ewert and M. J. B. Paynter, "Enumeration of bacteriophages and host bacteria in sewage and the activated-sludge treatment process," Applied and Environmental Microbiology, vol. 39, no. 3, pp. 576-583, 1980.

[15] K. Dabrowska, K. Switała-Jelen, A. Opolski, B. WeberDabrowska, and A. Gorski, "Bacteriophage penetration in vertebrates," Journal of Applied Microbiology, vol. 98, no. 1, pp. 7-13, 2005.

[16] H. W. Ackermann and D. Prangishvili, "Prokaryote viruses studied by electron microscopy," Archives of Virology, vol. 157, no. 10, pp. 1843-1849, 2012.

[17] J. Klumpp, R. Lavigne, M. J. Loessner, and H.-W. Ackermann, "The SPO1-related bacteriophages," Archives of Virology, vol. 155, no. 10, pp. 1547-1561, 2010.

[18] H.-W. Ackermann, "Frequency of morphological phage descriptions in the year 2000," Archives of Virology, vol. 146, no. 5, pp. 843-857, 2001.

[19] H. W. Ackermann, "Bacteriophage classification," in Bacteriophages: Biology and Applications, pp. 67-89, CRC Press, 2005.

[20] S. Matsuzaki, M. Rashel, J. Uchiyama et al., "Bacteriophage therapy: a revitalized therapy against bacterial infectious diseases," Journal of Infection and Chemotherapy, vol. 11, no. 5, pp. 211-219, 2005.

[21] S. Mc Grath and D. van Sinderen, Bacteriophage Genetics and Molecular Biology, 2007.

[22] J. W. Lengeler, G. Drews, and H. G. Schlegel, Biology of the Prokaryotes, 1999.

[23] S. Deresinski, "Bacteriophage therapy: exploiting smaller fleas," Clinical Infectious Diseases, vol. 48, no. 8, pp. 1096-1101, 2009.

[24] M. Parviz Sabour and W. Mansel Griffiths, Bacteriophages in the Control of Food and Waterborne Pathogens, American Society for Microbiology, 2010.

[25] A. Coffey and R. P. Ross, "Bacteriophage-resistance systems in dairy starter strains: molecular analysis to application," Antonie van Leeuwenhoek, vol. 82, no. 1-4, pp. 303-321, 2002.

[26] B. J. M. Bohannan and R. E. Lenski, "Linking genetic change to community evolution: insights from studies of bacteria and bacteriophage," Ecology Letters, vol. 3, no. 4, pp. 362-377, 2000. 
[27] B. R. Levin and J. J. Bull, "Population and evolutionary dynamics of phage therapy," Nature Reviews Microbiology, vol. 2, no. 2, pp. 166-173, 2004.

[28] D. H. Kruger and T. A. Bickle, "Bacteriophage survival: multiple mechanisms for avoiding the deoxyribonucleic acid restriction systems of their hosts," Microbiological Reviews, vol. 47, no. 3, pp. 345-360, 1983.

[29] F. J. M. Mojica, C. Ferrer, G. Juez, and F. Rodríguez-Valera, "Long stretches of short tandem repeats are present in the largest replicons of the Archaea Haloferax mediterranei and Haloferax volcanii and could be involved in replicon partitioning," Molecular Microbiology, vol. 17, no. 1, pp. 85-93, 1995.

[30] M. P. Terns and R. M. Terns, "CRISPR-based adaptive immune systems," Current Opinion in Microbiology, vol. 14, no. 3, pp. 321327, 2011.

[31] L. A. Marraffini and E. J. Sontheimer, "CRISPR interference: RNA-directed adaptive immunity in bacteria and archaea," Nature Reviews Genetics, vol. 11, no. 3, pp. 181-190, 2010.

[32] K. S. Makarova, D. H. Haft, R. Barrangou et al., "Evolution and classification of the CRISPR-Cas systems," Nature Reviews Microbiology, vol. 9, no. 6, pp. 467-477, 2011.

[33] O. Bergh, K. Y. Borsheim, G. Bratbak, and M. Heldal, "High abundance of viruses found in aquatic environments," Nature, vol. 340, no. 6233, pp. 467-468, 1989.

[34] Y. Wei, P. Ocampo, and B. R. Levin, "An experimental study of the population and evolutionary dynamics of Vibrio cholerae O1 and the bacteriophage JSF4," Proceedings of the Royal Society B: Biological Sciences, vol. 277, no. 1698, pp. 3247-3254, 2010.

[35] S. Mills, F. Shanahan, C. Stanton, C. Hill, A. Coffey, and P. R. Ross, "Movers and shakers: influence of bacteriophages in shaping the mammalian gut microbiota," Gut Microbes, vol. 1, pp. 4-16, 2013.

[36] H. Brussow, "Phages of dairy bacteria," Annual Review of Microbiology, vol. 55, pp. 283-303, 2001.

[37] C. Madera, C. Monjardín, and J. E. Suárez, "Milk contamination and resistance to processing conditions determine the fate of Lactococcus lactis bacteriophages in dairies," Applied and Environmental Microbiology, vol. 70, no. 12, pp. 7365-7371, 2004.

[38] D. Pattron, Public Health Safety of Bacteriophages in ReadyTo-Eat Meats \& Poultry Products, Food Safety, Public Health Scientist and Consultant in Trinidad Article Source, 2006.

[39] T. Bigwood, J. A. Hudson, C. Billington, G. V. Carey-Smith, and J. A. Heinemann, "Phage inactivation of foodborne pathogens on cooked and raw meat," Food Microbiology, vol. 25, no. 2, pp. 400-406, 2008.

[40] R. Bruynoghe and J. Maisin, "Essais de thérapeutique au moyen du bacteriophage," Comptes Rendus des Séances et Mémoires de la Société de Biologie, vol. 85, pp. 1120-1121, 1921.

[41] O. 'Flaherty S, R. P. Ross, and A. Coffey, "Bacteriophage and their lysins for elimination of infectiousbacteria," FEMS Microbiology Reviews, vol. 33, no. 4, pp. 801-819, 2009.

[42] W. C. Summers, "Bacteriophage research: early history," in Bacteriophages: Biology and Applications, E. Kutter and A. Sulakvelidze, Eds., pp. 5-27, CRC Press, 2005.

[43] H. Ruska, "Uber die Sichtbarmachung der bakteriophagen Lyse im mikroskop," Die Naturwissenschaften, vol. 28, no. 3, pp. 4546, 1940.

[44] A. Sulakvelidze and E. Kutter, "Bacteriophage therapy in humans," in Bacteriophages, Biology and Applications, E. Kutter and A. Sulakvelidze, Eds., chapter 14, pp. 381-436, CRC Press, 2005.
[45] O. McAuliffe, R. P. Ross, and G. F. Fitzgerald, "The new phage biology: from genomics to applications," in Bacteriophage: Genetics and Molecular Biology, S. McGrath and D. van Sinderen, Eds., Caister Academic, 2007.

[46] A. Sulakvelidze, "Phage therapy: an attractive option for dealing with antibiotic-resistant bacterial infections," Drug Discovery Today, vol. 10, no. 12, pp. 807-809, 2005.

[47] B. Weber-D,browska, M. Mulczyk, and A. Górski, "Bacteriophages as an efficient therapy for antibiotic-resistant septicemia in man," Transplantation Proceedings, vol. 35, no. 4, pp. 13851386, 2003.

[48] G. O. Klein, "Bacteriophage therapy can be the rescue when antibiotics no longer work," Lakartidningen, vol. 106, no. 40, pp. 2530-2533, 2009.

[49] S. I. Ahmad, "Treatment of post-burns bacterial infections by bacteriophages, specifically ubiquitous Pseudomonas spp. notoriously resistant to antibiotics," Medical Hypotheses, vol. 58, no. 4, pp. 327-331, 2002.

[50] B. Biswas, S. Adhya, P. Washart et al., "Bacteriophage therapy rescues mice bacteremic from a clinical isolate of vancomycinresistant Enterococcus faecium," Infection and Immunity, vol. 70, no. 1, pp. 204-210, 2002.

[51] J. Uchiyama, M. Rashel, I. Takemura, H. Wakiguchi, and S. Matsuzaki, "In silico and in vivo evaluation of bacteriophage $\varphi \mathrm{EF} 24 \mathrm{C}$, a candidate for treatment of Enterococcus faecalis infections," Applied and Environmental Microbiology, vol. 74, no. 13, pp. 4149-4163, 2008.

[52] J. Uchiyama, M. Rashel, Y. Maeda et al., "Isolation and characterization of a novel Enterococcus faecalis bacteriophage $\varphi \mathrm{EF} 24 \mathrm{C}$ as a therapeutic candidate," FEMS Microbiology Letters, vol. 278, no. 2, pp. 200-206, 2008.

[53] S. O'Flaherty, A. Coffey, W. Meaney, G. F. Fitzgerald, and R. P. Ross, "The recombinant phage lysin LysK has a broad spectrum of lytic activity against clinically relevant staphylococci, including methicillin-resistant Staphylococcus aureus," Journal of Bacteriology, vol. 187, no. 20, pp. 7161-7164, 2005.

[54] S. O’Flaherty, R. P. Ross, W. Meaney, G. F. Fitzgerald, M. F. Elbreki, and A. Coffey, "Potential of the Polyvalent antiStaphylococcus bacteriophage $\mathrm{K}$ for control of antibioticresistant staphylococci from hospitals," Applied and Environmental Microbiology, vol. 71, no. 4, pp. 1836-1842, 2005.

[55] C. S. Vinodkumar, Y. F. Neelagund, and S. Kalsurmath, "Bacteriophage in the treatment of experimental septicemic mice from a clinical isolate of multidrug resistant Klebsiella pneumoniae," Journal of Communicable Diseases, vol. 37, no. 1, pp. 18-29, 2005.

[56] J. Wang, B. Hu, M. Xu et al., "Therapeutic effectiveness of bacteriophages in the rescue of mice with extended spectrum $\beta$ lactamase-producing Escherichia coli bacteremia," International Journal of Molecular Medicine, vol. 17, no. 2, pp. 347-355, 2006.

[57] J. Wang, B. Hu, M. Xu et al., "Use of bacteriophage in the treatment of experimental animal bacteremia from imipenemresistant Pseudomonas aeruginosa," International Journal of Molecular Medicine, vol. 17, no. 2, pp. 309-317, 2006.

[58] C. Vinodkumar, S. Kalsurmath, and Y. Neelagund, "Utility of lytic bacteriophage in the treatment of multidrug-resistant Pseudomonas aeruginosa septicemia in mice," Indian Journal of Pathology and Microbiology, vol. 51, no. 3, pp. 360-366, 2008.

[59] A. Wright, C. H. Hawkins, E. E. Änggård, and D. R. Harper, "A controlled clinical trial of a therapeutic bacteriophage preparation in chronic otitis due to antibiotic-resistant Pseudomonas aeruginosa; a preliminary report of efficacy," Clinical Otolaryngology, vol. 34, no. 4, pp. 349-357, 2009. 
[60] M. Viscardi, A. G. Perugini, C. Auriemma et al., "Isolation and characterisation of two novel coliphages with high potential to control antibiotic-resistant pathogenic Escherichia coli (EHEC and EPEC)," International Journal of Antimicrobial Agents, vol. 31, no. 2, pp. 152-157, 2008.

[61] N. H. Mann, "The potential of phages to prevent MRSA infections," Research in Microbiology, vol. 159, no. 5, pp. 400405, 2008.

[62] J. A. Hermoso, J. L. García, and P. García, "Taking aim on bacterial pathogens: from phage therapy to enzybiotics," Current Opinion in Microbiology, no. 5, pp. 461-472, 2007.

[63] N. K. Petty, T. J. Evans, P. C. Fineran, and G. P. C. Salmond, "Biotechnological exploitation of bacteriophage research," Trends in Biotechnology, vol. 25, no. 1, pp. 7-15, 2007.

[64] R. López, E. García, and P. García, "Enzymes for anti-infective therapy: phage lysins," Drug Discovery Today, vol. 1, no. 4, pp. 469-474, 2004.

[65] C. R. Merril, B. Biswas, R. Carlton et al., "Long-circulating bacteriophage as antibacterial agents," Proceedings of the National Academy of Sciences of the United States of America, vol. 93, no. 8, pp. 3188-3192, 1996.

[66] M. Skurnik and E. Strauch, "Phage therapy: facts and fiction," International Journal of Medical Microbiology, vol. 296, no. 1, pp. 5-14, 2006.

[67] J. Borysowski and A. Górski, "Is phage therapy acceptable in the immunocompromised host?" International Journal of Infectious Diseases, vol. 12, no. 5, pp. 466-471, 2008.

[68] S. Slopek, A. Kucharewicz-Krukowska, B. Weber-Dabrowska, and M. Dabrowski, "Evaluation of the results obtained in children," Archivum Immunologiae et Therapiae Experimentalis, vol. 33, no. 2, pp. 241-259, 1985.

[69] S. Slopek, B. Weber-Dabrowska, M. Dabrowski, and A. Kucharewicz-Krukowska, "Results of bacteriophage treatment of suppurative bacterial infections in the years 1981-1986," Archivum Immunologiae et Therapiae Experimentalis, vol. 35, no. 5, pp. 569-583, 1987.

[70] M. Cislo, M. Dabrowski, B. Weber-Dabrowska, and A. Woyton, "Bacteriophage treatment of suppurative skin infections," Archivum Immunologiae et Therapiae Experimentalis, vol. 35, no. 2, pp. 175-183, 1987.

[71] B. Weber-D,browska, M. Mulczyk, and A. Górski, "Bacteriophage therapy of bacterial infections: an update of our institute's experience," Archivum Immunologiae et Therapiae Experimentalis, vol. 48, no. 6, pp. 547-551, 2000.

[72] J. Alisky, K. Iczkowski, A. Rapoport, and N. Troitsky, "Bacteriophages show promise as antimicrobial agents," Journal of Infection, vol. 36, no. 1, pp. 5-15, 1998.

[73] A. Almeida, Â. Cunha, N. C. M. Gomes, E. Alves, L. Costa, and M. A. F. Faustino, "Phage therapy and photodynamic therapy: low environmental impact approaches to inactivate microorganisms in fish farming plants," Marine Drugs, vol. 7, no. 3, pp. 268-313, 2009.

[74] R. Międzybrodzki, J. Borysowski, B. Weber-Dąbrowska et al., "Clinical aspects of phage therapy," Advances in Virus Research, vol. 83, pp. 73-121, 2012.

[75] J. S. Soothill, "Bacteriophage prevents destruction of skin grafts by Pseudomonas aeruginosa," Burns, vol. 20, no. 3, pp. 209-211, 1994.

[76] A. Bruttin and H. Brüssow, "Human volunteers receiving Escherichia coli phage T4 orally: a safety test of phage therapy," Antimicrobial Agents and Chemotherapy, vol. 49, no. 7, pp. 28742878, 2005.
[77] S. A. Sarker, S. McCallin, C. Barretto et al., "Oral T4-like phage cocktail application to healthy adult volunteers from Bangladesh," Virology, vol. 434, no. 2, pp. 222-232, 2012.

[78] H. Nishikawa, M. Yasuda, J. Uchiyama et al., "T-even-related bacteriophages as candidates for treatment of Escherichia coli urinary tract infections," Archives of Virology, vol. 153, no. 3, pp. 507-515, 2008.

[79] E. M. Ryan, S. P. Gorman, R. F. Donnelly, and B. F. Gilmore, "Recent advances in bacteriophage therapy: how delivery routes, formulation, concentration and timing influence the success of phage therapy," Journal of Pharmacy and Pharmacology, vol. 63, no. 10, pp. 1253-1264, 2011.

[80] S. Chhibber, S. Kaur, and S. Kumari, "Therapeutic potential of bacteriophage in treating Klebsiella pneumoniae B5055mediated lobar pneumonia in mice," Journal of Medical Microbiology, vol. 57, no. 12, pp. 1508-1513, 2008.

[81] Q. F. Wills, C. Kerrigan, and J. S. Soothill, "Experimental bacteriophage protection against Staphylococcus aureus abscesses in a rabbit model," Antimicrobial Agents and Chemotherapy, vol. 49, no. 3, pp. 1220-1221, 2005.

[82] J. Azeredo and I. W. Sutherland, "The use of phages for the removal of infectious biofilms," Current Pharmaceutical Biotechnology, vol. 9, no. 4, pp. 261-266, 2008.

[83] M. M. Doolittle, J. J. Cooney, and D. E. Caldwell, "Lytic infection of Escherichia coli biofilms by bacteriophage T4," Canadian Journal of Microbiology, vol. 41, no. 1, pp. 12-18, 1995.

[84] J. B. Jones, L. E. Jackson, B. Balogh, A. Obradovic, F. B. Iriarte, and M. T. Momol, "Bacteriophages for plant disease control," Annual Review of Phytopathology, vol. 45, pp. 245-262, 2007.

[85] D. Kelly, O. Mcauliffe, R. P. Ross, and A. Coffey, "Prevention of Staphylococcus aureus biofilm formation and reduction in established biofilm density using a combination of phage $\mathrm{K}$ and modified derivatives," Letters in Applied Microbiology, vol. 54, no. 4, pp. 286-291, 2012.

[86] P. Lacroix-Gueu, R. Briandet, S. Lévêque-Fort, M.-N. BellonFontaine, and M.-P. Fontaine-Aupart, "In situ measurements of viral particles diffusion inside mucoid biofilms," Comptes Rendus Biologies, vol. 328, no. 12, pp. 1065-1072, 2005.

[87] V. A. Fischetti, "The use of phage lytic enzymes to control bacterial infections," in Bacteriophages, Biology and Applications, E. Kutter and A. Sulakvelidze, Eds., chapter 12, pp. 321-334, CRC Press, 2005.

[88] V. A. Fischetti, "Bacteriophage lytic enzymes: novel antiinfectives," Trends in Microbiology, vol. 13, no. 10, pp. 491-496, 2005.

[89] R. Young, "Bacteriophage lysis: mechanism and regulation," Microbiological Reviews, vol. 56, no. 3, pp. 430-481, 1992.

[90] R. Young, I.-N. Wang, and W. D. Roof, "Phages will out: strategies of host cell lysis," Trends in Microbiology, vol. 8, no. 3, pp. 120-128, 2000.

[91] M. J. Loessner, K. Kramer, F. Ebel, and S. Scherer, "Cterminal domains of Listeria monocytogenes bacteriophage murein hydrolases determine specific recognition and highaffinity binding to bacterial cell wall carbohydrates," Molecular Microbiology, vol. 44, no. 2, pp. 335-349, 2002.

[92] R. Young and U. Bläsi, "Holins: form and function in bacteriophage lysis," FEMS Microbiology Reviews, vol. 17, no. 1-2, pp. 191205, 1995.

[93] I.-N. Wang, D. L. Smith, and R. Young, "Holins: the protein clocks of bacteriophage infections," Annual Review of Microbiology, vol. 54, pp. 799-825, 2000. 
[94] E. Diaz, R. Lopez, and J. L. Garcia, "Chimeric phage-bacterial enzymes: a clue to the modular evolution of genes," Proceedings of the National Academy of Sciences of the United States of America, vol. 87, no. 20, pp. 8125-8129, 1990.

[95] P. García, J. L. García, E. García, J. M. Sánchez-Puelles, and R. López, "Modular organization of the lytic enzymes of Streptococcus pneumoniae and its bacteriophages," Gene, vol. 86, no. 1, pp. 81-88, 1990.

[96] M. J. Loessner, "Bacteriophage endolysins-current state of research and applications," Current Opinion in Microbiology, vol. 8, no. 4, pp. 480-487, 2005.

[97] M. Larkin, "Vincent Fischetti-following phages for life," Lancet Infectious Diseases, vol. 4, no. 4, pp. 246-249, 2004.

[98] W. W. Navarre, H. Ton-That, K. F. Faull, and O. Schneewind, "Multiple enzymatic activities of the murein hydrolase from staphylococcal phage $\varphi 11$ : identification of a D-alanyl-glycine endopeptidase activity," Journal of Biological Chemistry, vol. 274, no. 22, pp. 15847-15856, 1999.

[99] M. Rashel, J. Uchiyama, T. Ujihara et al., "Efficient elimination of multidrug-resistant Staphylococcus aureus by cloned lysin derived from bacteriophage $\varphi$ MR11," Journal of Infectious Diseases, vol. 196, no. 8, pp. 1237-1247, 2007.

[100] R. López and E. García, "Recent trends on the molecular biology of pneumococcal capsules, lytic enzymes, and bacteriophage," FEMS Microbiology Reviews, vol. 28, no. 5, pp. 553-580, 2004.

[101] V. A. Fischetti, "Bacteriophage lysins as effective antibacterials," Current Opinion in Microbiology, vol. 11, no. 5, pp. 393-400, 2008.

[102] H. Oliveira, L. D. Melo, S. B. Santos et al., "Molecular aspects and comparative genomics of bacteriophage endolysins," Journal of Virology, vol. 87, no. 8, pp. 4558-4570, 2013.

[103] P. García, L. Rodríguez, A. Rodríguez, and B. Martínez, "Food biopreservation: promising strategies using bacteriocins, bacteriophages and endolysins," Trends in Food Science and Technology, vol. 21, no. 8, pp. 373-382, 2010.

[104] V. A. Fischetti, "Bacteriophage endolysins: a novel anti-infective to control Gram-positive pathogens," International Journal of Medical Microbiology, vol. 300, no. 6, pp. 357-362, 2010.

[105] J. M. Loeffler, D. Nelson, and V. A. Fischetti, "Rapid killing of Streptococcus pneumoniae with a bacteriophage cell wall hydrolase," Science, vol. 294, no. 5549, pp. 2170-2172, 2001.

[106] D. Nelson, L. Loomis, and V. A. Fischetti, "Prevention and elimination of upper respiratory colonization of mice by group A streptococci by using a bacteriophage lytic enzyme," Proceedings of the National Academy of Sciences of the United States of America, vol. 98, no. 7, pp. 4107-4112, 2001.

[107] I. Jado, R. López, E. García et al., "Phage lytic enzymes as therapy for antibiotic-resistant Streptococcus pneumoniae infection in a murine sepsis model," Journal of Antimicrobial Chemotherapy, vol. 52, no. 6, pp. 967-973, 2003.

[108] J. A. McCullers, Å. Karlström, A. R. Iverson, J. M. Loeffler, and V. A. Fischetti, "Novel strategy to prevent otitis media caused by colonizing Streptococcus pneumoniae," PLoS Pathogens, vol. 3, article e28, 2007.

[109] R. Schuch, D. Nelson, and V. A. Fischetti, "A bacteriolytic agent that detects and kills Bacillus anthracis," Nature, vol. 418, no. 6900, pp. 884-889, 2002.

[110] P. Yoong, R. Schuch, D. Nelson, and V. A. Fischetti, "PlyPH, a bacteriolytic enzyme with a broad $\mathrm{pH}$ range of activity and lytic action against Bacillus anthracis," Journal of Bacteriology, vol. 188, no. 7, pp. 2711-2714, 2006.
[111] L. K. Celia, D. Nelson, and D. E. Kerr, "Characterization of a bacteriophage lysin (Ply700) from Streptococcus uberis," Veterinary Microbiology, vol. 130, no. 1-2, pp. 107-117, 2008.

[112] J. M. Obeso, B. Martínez, A. Rodríguez, and P. García, "Lytic activity of the recombinant staphylococcal bacteriophage PhiH5 endolysin active against Staphylococcus aureus in milk," International Journal of Food Microbiology, vol. 128, no. 2, pp. 212-218, 2008.

[113] Y. Wang, J. H. Sun, and C. P. Lu, "Purified recombinant phage lysin LySMP: an extensive spectrum of lytic activity for swine streptococci," Current Microbiology, vol. 58, no. 6, pp. 609-615, 2009.

[114] P. Yoong, R. Schuch, D. Nelson, and V. A. Fischetti, "Identification of a broadly active phage lytic enzyme with lethal activity against antibiotic-resistant Enterococcus faecalis and Enterococcus faecium," Journal of Bacteriology, vol. 186, no. 14, pp. 4808-4812, 2004.

[115] M. Zimmer, N. Vukov, S. Scherer, and M. J. Loessner, "The murein hydrolase of the bacteriophage $\varphi 3626$ dual lysis system is active against all tested Clostridium perfringens strains," Applied and Environmental Microbiology, vol. 68, no. 11, pp. 5311-5317, 2002.

[116] M. Walmagh, Y. Briers, S. B. dos Santos, J. Azeredo, and R. Lavigne, "Characterization of modular bacteriophage endolysins from Myoviridaephages OBP, 201 2 2-1 and PVP-SE1," PLoS ONE, vol. 7, no. 5, Article ID e36991, 2012.

[117] Y. Briers, M. Walmagh, and R. Lavigne, "Use of bacteriophage endolysin EL188 and outer membrane permeabilizers against Pseudomonas aeruginosa," Journal of Applied Microbiology, vol. 110, no. 3, pp. 778-785, 2011.

[118] H. R. Ibrahim, M. Yamada, K. Matsushita, K. Kobayashi, and A. Kato, "Enhanced bactericidal action of lysozyme to Escherichia coli by inserting a hydrophobic pentapeptide into its C terminus," Journal of Biological Chemistry, vol. 269, no. 7, pp. 5059-5063, 1994.

[119] H. W. Smith and M. B. Huggins, "Successful treatment of experimental Escherichia coli infections in mice using phage: its general superiority over antibiotics," Journal of General Microbiology, vol. 128, no. 2, pp. 307-318, 1982.

[120] G. G. Bogovazova, N. N. Voroshilova, and V. M. Bondarenko, "The efficacy of Klebsiella pneumoniae bacteriophage in the therapy of experimental Klebsiella infection," Zhurnal Mikrobiologii Epidemiologii i Immunobiologii, vol. 68, no. 4, pp. 5-8, 1991.

[121] P. Barrow, M. Lovell, and A. Berchieri Jr., "Use of lytic bacteriophage for control of experimental Escherichia coli septicemia and meningitis in chickens and calves," Clinical and Diagnostic Laboratory Immunology, vol. 5, no. 3, pp. 294-298, 1998.

[122] V. Rdamesh, Bacteriophage Therapy of Clostridium DifficileAssociated Intestinal Disease in a Hamster Model Miroecol Anarobes, 1999.

[123] J. Cao, Y.-Q. Sun, T. Berglindh et al., "Helicobacter pyloriantigen-binding fragments expressed on the filamentous M13 phage prevent bacterial growth," Biochimica et Biophysica Acta, vol. 1474, no. 1, pp. 107-113, 2000.

[124] K. E. Cerveny, A. DePaola, D. H. Duckworth, and P. A. Gulig, "Phage therapy of local and systemic disease caused by Vibrio vulnificus in iron-dextran-treated mice," Infection and Immunity, vol. 70, no. 11, pp. 6251-6262, 2002.

[125] J. J. Bull, B. R. Levin, T. DeRouin, N. Walker, and C. A. Bloch, "Dynamics of success and failure in phage and antibiotic 
therapy in experimental infections," BMC Microbiology, vol. 2, article 1, 2002.

[126] S. Matsuzaki, M. Yasuda, H. Nishikawa et al., "Experimental protection of mice against lethal staphylococcus aureus infection by novel bacteriophage $\varphi \mathrm{MR} 11$," The Journal of Infectious Diseases, vol. 187, no. 4, pp. 613-624, 2003.

[127] D. Goode, V. M. Allen, and P. A. Barrow, "Reduction of experimental Salmonella and Campylobacter contamination of chicken skin by application of lytic bacteriophages," Applied and Environmental Microbiology, vol. 69, no. 8, pp. 5032-5036, 2003.

[128] S. Hagens, A. Habel, U. von Ahsen, A. von Gabain, and U. Bläsi, "Therapy of experimental Pseudomonas infections with a nonreplicating genetically modified phage," Antimicrobial Agents and Chemotherapy, vol. 48, no. 10, pp. 3817-3822, 2004.

[129] Y. Tanji, T. Shimada, H. Fukudomi, K. Miyanaga, Y. Nakai, and H. Unno, "Therapeutic use of phage cocktail for controlling Escherichia coli O157:H7 in gastrointestinal tract of mice," Journal of Bioscience and Bioengineering, vol. 100, no. 3, pp. 280287, 2005.

[130] L. Fiorentin, N. D. Vieira, and W. Barioni Júnior, "Use of lytic bacteriophages to reduce Salmonella enteritidis in experimentally contaminated chicken cuts," Revista Brasileira de Ciência Avícola, vol. 7, pp. 255-260, 2005.

[131] H. Toro, S. B. Price, S. McKee et al., "Use of bacteriophages in combination with competitive exclusion to reduce Salmonella from infected chickens," Avian Diseases, vol. 49, no. 1, pp. 118124, 2005.

[132] M. G. Vinod, M. M. Shivu, K. R. Umesha et al., "Isolation of Vibrio harveyi bacteriophage with a potential for biocontrol of luminous vibriosis in hatchery environments," Aquaculture, vol. 255, no. 1-4, pp. 117-124, 2006.

[133] C. S. McVay, M. Velásquez, and J. A. Fralick, "Phage therapy of Pseudomonas aeruginosa infection in a mouse burn wound model," Antimicrobial Agents and Chemotherapy, vol. 51, no. 6, pp. 1934-1938, 2007.

[134] R. Watanabe, T. Matsumoto, G. Sano et al., "Efficacy of bacteriophage therapy against gut-derived sepsis caused by Pseudomonas aeruginosa in mice," Antimicrobial Agents and Chemotherapy, vol. 51, no. 2, pp. 446-452, 2007.

[135] S. Kumari, K. Harjai, and S. Chhibber, "Topical treatment of klebsiella pneumoniae B5055 induced burn wound infection in mice using natural products," Journal of Infection in Developing Countries, vol. 4, no. 6, pp. 367-377, 2010.

[136] B. R. Tiwari, S. Kim, M. Rahman, and J. Kim, "Antibacterial efficacy of lytic Pseudomonas bacteriophage in normal and neutropenic mice models," Journal of Microbiology, vol. 49, no. 6, pp. 994-999, 2011.

[137] D. Alemayehu, P. G. Casey, O. Mcauliffe et al., "Bacteriophages $\varphi \mathrm{MR} 299-2$ and $\varphi \mathrm{NH}-4$ can eliminate Pseudomonas aeruginosa in the murine lung and on cystic fibrosis lung airway cells," mBio, vol. 3, no. 2, 2012.

[138] F. Pouillot, M. Chomton, H. Blois et al., "Efficacy of bacteriophage therapy in experimental sepsis and meningitis caused by a clone O25b:H4-ST131 Escherichia coli strain producing CTXM-15," Antimicrobial Agents and Chemotherapy, vol. 56, no. 7, pp. 3568-3575, 2012.

[139] M. M. Doolittle, J. J. Cooney, and D. E. Caldwell, "Tracing the interaction of bacteriophage with bacterial biofilms using fluorescent and chromogenic probes," Journal of Industrial Microbiology, vol. 16, no. 6, pp. 331-341, 1996.

[140] K. A. Hughes, I. W. Sutherland, and M. V. Jones, "Biofilm susceptibility to bacteriophage attack: the role of phage-borne polysaccharide depolymerase," Microbiology, vol. 144, no. 11, pp. 3039-3047, 1998.

[141] B. D. Corbin, R. J. C. McLean, and G. M. Aron, "Bacteriophage T4 multiplication in a glucose-limited Escherichia coli biofilm," Canadian Journal of Microbiology, vol. 47, no. 7, pp. 680-684, 2001.

[142] S. Sillankorva, R. Oliveira, M. J. Vieira, I. W. Sutherland, and J. Azeredo, "Bacteriophage $\Phi$ S1 infection of Pseudomonas fluorescens planktonic cells versus biofilms," Biofouling, vol. 20, no. 3, pp. 133-138, 2004.

[143] M. Sharma, J.-H. Ryu, and L. R. Beuchat, "Inactivation of Escherichia coli O157:H7 in biofilm on stainless steel by treatment with an alkaline cleaner and a bacteriophage," Journal of Applied Microbiology, vol. 99, no. 3, pp. 449-459, 2005.

[144] S. Sillankorva, R. Oliveira, M. J. Vieira, and J. Azeredo, "Realtime quantification of Pseudomonas fluorescens cell removal from glass surfaces due to bacteriophage $\varphi S 1$ application," Journal of Applied Microbiology, vol. 105, no. 1, pp. 196-202, 2008.

[145] V. Verma, K. Harjai, and S. Chhibber, "Structural changes induced by a lytic bacteriophage make ciprofloxacin effective against older biofilm of Klebsiella pneumoniae," Biofouling, vol. 26, no. 6, pp. 729-737, 2010.

[146] K. A. Soni and R. Nannapaneni, "Removal of listeria monocytogenes biofilms with bacteriophage P100," Journal of Food Protection, vol. 73, no. 8, pp. 1519-1524, 2010.

[147] M. Rahman, S. Kim, S. M. Kim, S. Y. Seol, and J. Kim, "Characterization of induced Staphylococcus aureus bacteriophage SAP26 and its anti-biofilm activity with rifampicin," Biofouling, vol. 27, no. 10, pp. 1087-1093, 2011.

[148] D. Pires, S. Sillankorva, A. Faustino, and J. Azeredo, "Use of newly isolated phages for control of Pseudomonas aeruginosa PAO1 and ATCC 10145 biofilms," Research in Microbiology, vol. 162, no. 8, pp. 798-806, 2011.

[149] A. Chibeu, E. J. Lingohr, L. Masson et al., "Bacteriophages with the ability to degrade uropathogenic Escherichia Coli biofilms," Viruses, vol. 4, no. 4, pp. 471-487, 2012.

[150] A. B. Yele, N. D. Thawal, P. K. Sahu, and B. A. Chopade, "Novel lytic bacteriophage AB7-IBB1 of Acinetobacter baumannii: isolation, characterization and its effect on biofilm," Archives of Virology, vol. 157, no. 8, pp. 1441-1450, 2012.

[151] N. D. Thawal, A. B. Yele, P. K. Sahu, and B. A. Chopade, "Effect of a Novel Podophage AB7-IBB2 on Acinetobacter baumannii Biofilm," Current Microbiology, vol. 65, no. 1, pp. 66-72, 2012.

[152] J. T. Hoopes, C. J. Stark, H. A. Kim, D. J. Sussman, D. M. Donovan, and D. C. Nelson, "Use of a bacteriophage lysin, PlyC, as an enzyme disinfectant against Streptococcus equi," Applied and Environmental Microbiology, vol. 75, no. 5, pp. 1388-1394, 2009.

[153] D. G. Pritchard, S. Dong, J. R. Baker, and J. A. Engler, "The bifunctional peptidoglycan lysin of Streptococcus agalactiae bacteriophage B30," Microbiology, vol. 150, no. 7, pp. 2079-2087, 2004.

[154] M. Takáč, A. Witte, and U. Bläsi, "Functional analysis of the lysis genes of Staphylococcus aureus phage P68 in Escherichia coli," Microbiology, vol. 151, no. 7, pp. 2331-2342, 2005.

[155] S. Gaeng, S. Scherer, H. Neve, and M. J. Loessner, "Gene cloning and expression and secretion of Listeria monocytogenes bacteriophage-lyric enzymes in Lactococcus lactis," Applied and Environmental Microbiology, vol. 66, no. 7, pp. 2951-2958, 2000. 
[156] D. G. Pritchard, S. Dong, M. C. Kirk, R. T. Cartee, and J. R. Baker, "LambdaSal and LambdaSa2 prophage lysins of Streptococcus agalactiae," Applied and Environmental Microbiology, vol. 73, no. 22, pp. 7150-7154, 2007.

[157] C. J. Porter, R. Schuch, A. J. Pelzek et al., "The 1.6 A crystal structure of the catalytic domain of PlyB, a bacteriophage lysin active against Bacillus anthracis," Journal of Molecular Biology, vol. 366, no. 2, pp. 540-550, 2007.

[158] P. Sass and G. Bierbaum, "Lytic activity of recombinant bacteriophage $\varphi 11$ and $\varphi 12$ endolysins on whole cells and biofilms of Staphylococcus aureus," Applied and Environmental Microbiology, vol. 73, no. 1, pp. 347-352, 2007.

[159] K.-J. Yokoi, N. Kawahigashi, M. Uchida et al., "The twocomponent cell lysis genes holWMY and lysWMY of the Staphylococcus warneri M phage $\varphi$ WMY: cloning, sequencing, expression, and mutational analysis in Escherichia coli," Gene, vol. 351, pp. 97-108, 2005.

[160] Q. Cheng, D. Nelson, S. Zhu, and V. A. Fischetti, "Removal of group B streptococci colonizing the vagina and oropharynx of mice with a bacteriophage lytic enzyme," Antimicrobial Agents and Chemotherapy, vol. 49, no. 1, pp. 111-117, 2005.

[161] M. J. Mayer, A. Narbad, and M. J. Gasson, "Molecular characterization of a Clostridium difficile bacteriophage and its cloned biologically active endolysin," Journal of Bacteriology, vol. 190, no. 20, pp. 6734-6740, 2008.

[162] A. L. Delisle, G. J. Barcak, and M. Guo, "Isolation and expression of the lysis genes of Actinomyces naeslundii phage Av-1," Applied and Environmental Microbiology, vol. 72, no. 2, pp. 11101117, 2006.

[163] K. Sugahara, K.-J. Yokoi, Y. Nakamura et al., "Mutational and biochemical analyses of the endolysin LysgaY encoded by the Lactobacillus gasseri JCM 1131 T phage $\varphi$ gaY," Gene, vol. 404, no. 1-2, pp. 41-52, 2007.

[164] K. Mishra, M. Rawat, K. N. Viswas, Abhishek, S. Kumar, and M. Reddy, "Expression and lytic efficacy assessment of the Staphylococcus aureus phage SA4 lysin gene," Journal of Veterinary Science, vol. 14, no. 1, pp. 37-43, 2013.

[165] M. Schmelcher, O. Korobova, N. Schischkova et al., "Staphylococcus haemolyticus prophage $\Phi \mathrm{SH} 2$ endolysinrelies on cysteine, histidine-dependent amidohydrolases/peptidases activity for lysis 'from without"' Journal of Biotechnology, vol. 162, no. 23, pp. 289-298, 2012.

[166] Y. Yuan, Q. Peng, and M. Gao, "Characteristics of a broad lytic spectrum endolysin from phage BtCS33 of Bacillus thuringiensis," BMC Microbiology, vol. 12, article 297, 2012.

[167] M. R. Eugster and M. J. Loessner, "Wall teichoic acids restrict access of bacteriophage endolysin Ply118, Ply511, and PlyP40 cell wall binding domains to the Listeria monocytogenes peptidoglycan," Journal of Bacteriology, vol. 194, no. 23, pp. 6498-6506, 2012.

[168] H. Zhang, H. Bao, C. Billington, J. A. Hudson, and R. Wang, "Isolation and lytic activity of the Listeria bacteriophage endolysin LysZ5 against Listeria monocytogenes in soya milk," Food Microbiology, vol. 31, no. 1, pp. 133-136, 2012.

[169] J. Park, J. Yun, J. A. Lim, D. H. Kang, and S. Ryu, "Characterization of an endolysin, LysBPS13, from a Bacillus cereus bacteriophage," FEMS Microbiology Letters, vol. 332, no. 1, pp. 76-83, 2012.

[170] J. Gu, R. Lu, X. Liu et al., "LysGH15B, the SH3b domain of staphylococcal phage endolysin LysGH15, retains high affinity to staphylococci," Current Microbiology, vol. 63, no. 6, pp. 538$542,2011$.
[171] L. Rodríguez, B. Martínez, Y. Zhou, A. Rodríguez, D. M. Donovan, and P. García, "Lytic activity of the virion-associated peptidoglycan hydrolase HydH5 of Staphylococcus aureus bacteriophage vB-SauS-phiIPLA88," BMC Microbiology, vol. 11, article 138, 2011.

[172] D. Proença, S. Fernandes, C. Leandro et al., "Phage endolysins with broad antimicrobial activity against Enterococcus faecalis clinical strains," Microb Drug Resist, vol. 18, no. 3, pp. 322-332, 2012.

[173] R. Gupta and Y. Prasad, "P-27/HP endolysin as antibacterial agent for antibiotic resistant Staphylococcus aureus of human infections," Current Microbiology, vol. 63, no. 1, pp. 39-45, 2011.

[174] H. Nariya, S. Miyata, E. Tamai, H. Sekiya, J. Maki, and A. Okabe, "Identification and characterization of a putative endolysin encoded by episomal phage phiSM101 of Clostridium perfringens," Applied Microbiology and Biotechnology, vol. 90, no. 6, pp. 1973-1979, 2011.

[175] M. J. Mayer, M. J. Gasson, and A. Narbad, "Genomic sequence of bacteriophage ATCC, 8074-B1 and activity of its endolysin and engineered variants against Clostridium sporogenes," Applied and Environmental Microbiology, vol. 78, no. 10, pp. 3685-3692, 2012.

[176] J.-A. Lim, H. Shin, D.-H. Kang, and S. Ryu, "Characterization of endolysin from a Salmonella Typhimurium-infecting bacteriophage SPN1S," Research in Microbiology, vol. 163, no. 3, pp. 233-241, 2012.

[177] J. Wittmann, R. Eichenlaub, and B. Dreiseikelmann, "The endolysins of bacteriophages CMP1 and CN77 are specific for the lysis of Clavibacter michiganensis strains," Microbiology, vol. 156, no. 8, pp. 2366-2373, 2010.

[178] M.-J. Lai, N.-T. Lin, A. Hu et al., "Antibacterial activity of Acinetobacter baumannii phage $\Phi \mathrm{aB} 2$ endolysin (LysAB2) against both Gram-positive and Gram-negative bacteria," Applied Microbiology and Biotechnology, vol. 90, no. 2, pp. 529-539, 2011.

[179] B. Son, J. Yun, J.-A. Lim, H. Shin, S. Heu, and S. Ryu, "Characterization of LysB4, an endolysin from the Bacillus cereus-infecting bacteriophage B4," BMC Microbiology, vol. 12, article 33, 2012.

[180] M. J. Mayer, J. Payne, M. J. Gasson, and A. Narbad, "Genomic sequence and characterization of the virulent bacteriophage $\varphi$ CTP1 from Clostridium tyrobutyricum and heterologous expression of its endolysin," Applied and Environmental Microbiology, vol. 76, no. 16, pp. 5415-5422, 2010.

[181] Y. Briers, G. Volckaert, A. Cornelissen et al., "Muralytic activity and modular structure of the endolysins of Pseudomonas aeruginosa bacteriophages $\varphi \mathrm{KZ}$ and EL," Molecular Microbiology, vol. 65, no. 5, pp. 1334-1344, 2007.

[182] J. Mao, M. Schmelcher, W. J. Harty, J. Foster-Frey, and D. M. Donovan, "Chimeric Ply187 endolysin kills Staphylococcus aureus more effectively than the parental enzyme," FEMS Microbiology Letters, vol. 342, no. 1, pp. 30-36, 2013.

[183] M. R. Eugster, M. C. Haug, S. G. Huwiler, and M. J. Loessner, "The cell wall binding domain of Listeria bacteriophage endolysin PlyP35 recognizes terminal GlcNAc residues in cell wall teichoic acid," Molecular Microbiology, vol. 81, no. 6, pp. 1419-1432, 2011.

[184] S. Hu, J. Kong, W. Kong, T. Guo, and M. Ji, "Characterization of a novel LysM domain from lactobacillus fermentam bacteriophage endolysin and its use as an anchor to display heterologous proteins on the surfaces of lactic acid bacteria," Applied and Environmental Microbiology, vol. 76, no. 8, pp. 2410-2418, 2010. 
[185] N. Bustamante, N. E. Campillo, E. García et al., "Cpl-7, a lysozyme encoded by a pneumococcal bacteriophage with a novel cell wall-binding motif," Journal of Biological Chemistry, vol. 285, no. 43, pp. 33184-33196, 2010.

[186] M. Gerova, N. Halgasova, J. Ugorcakova, and G. Bukovska, "Endolysin of bacteriophage BFK20: evidence of a catalytic and a cell wall binding domain," FEMS Microbiology Letters, vol. 321, no. 2, pp. 83-91, 2011.

[187] J. S. Son, S. Y. Jun, E. B. Kim et al., "Complete genome sequence of a newly isolated lytic bacteriophage, EFAP-1 of Enterococcus faecalis, and antibacterial activity of its endolysin EFAL-1," Journal of Applied Microbiology, vol. 108, no. 5, pp. 1769-1779, 2010.

[188] D. R. Roach, P. A. Khatibi, K. M. Bischoff, S. R. Hughes, and D. M. Donovan, "Bacteriophage-encoded lytic enzymes control growth of contaminating Lactobacillus found in fuel ethanol fermentations," Biotechnology for Biofuels, vol. 6, no. 1, article 20, 2013.

[189] S. Y. Jun, G. M. Jung, S. J. Yoon et al., "Antibacterial properties of a pre-formulated recombinant phage endolysin, SAL-1," International Journal of Antimicrobial Agents, vol. 41, no. 2, pp. 156-161, 2013. 

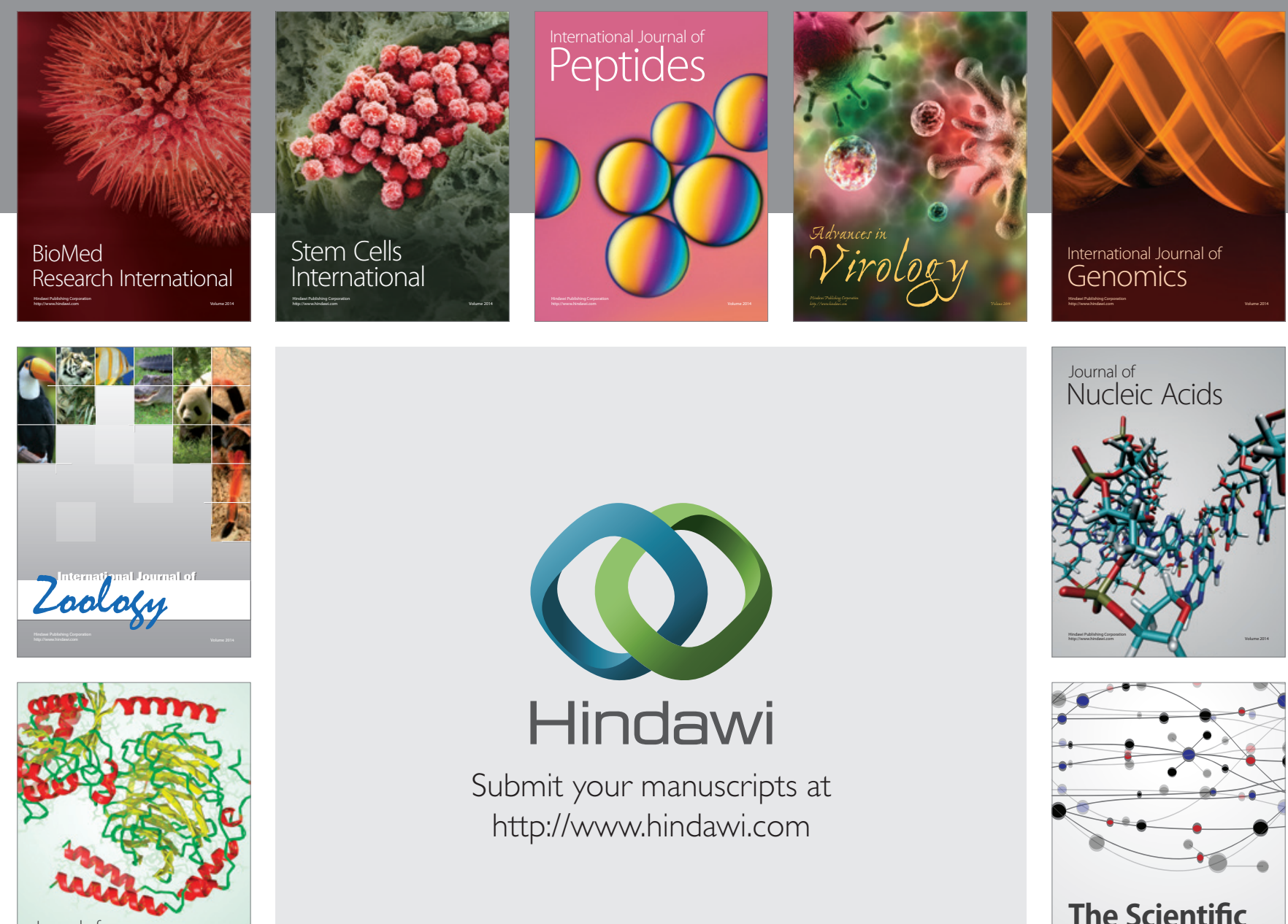

Submit your manuscripts at

http://www.hindawi.com

Journal of
Signal Transduction
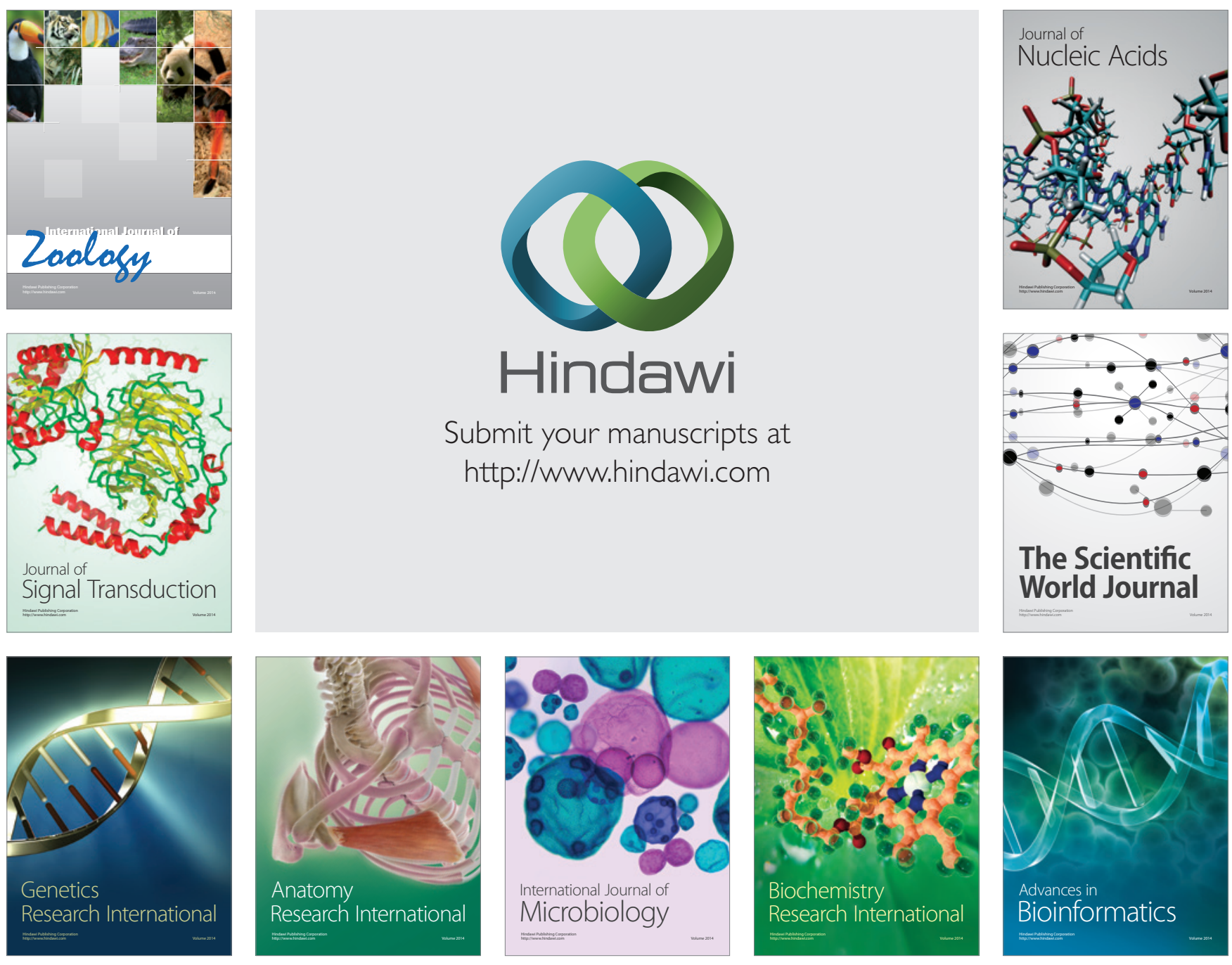

The Scientific World Journal
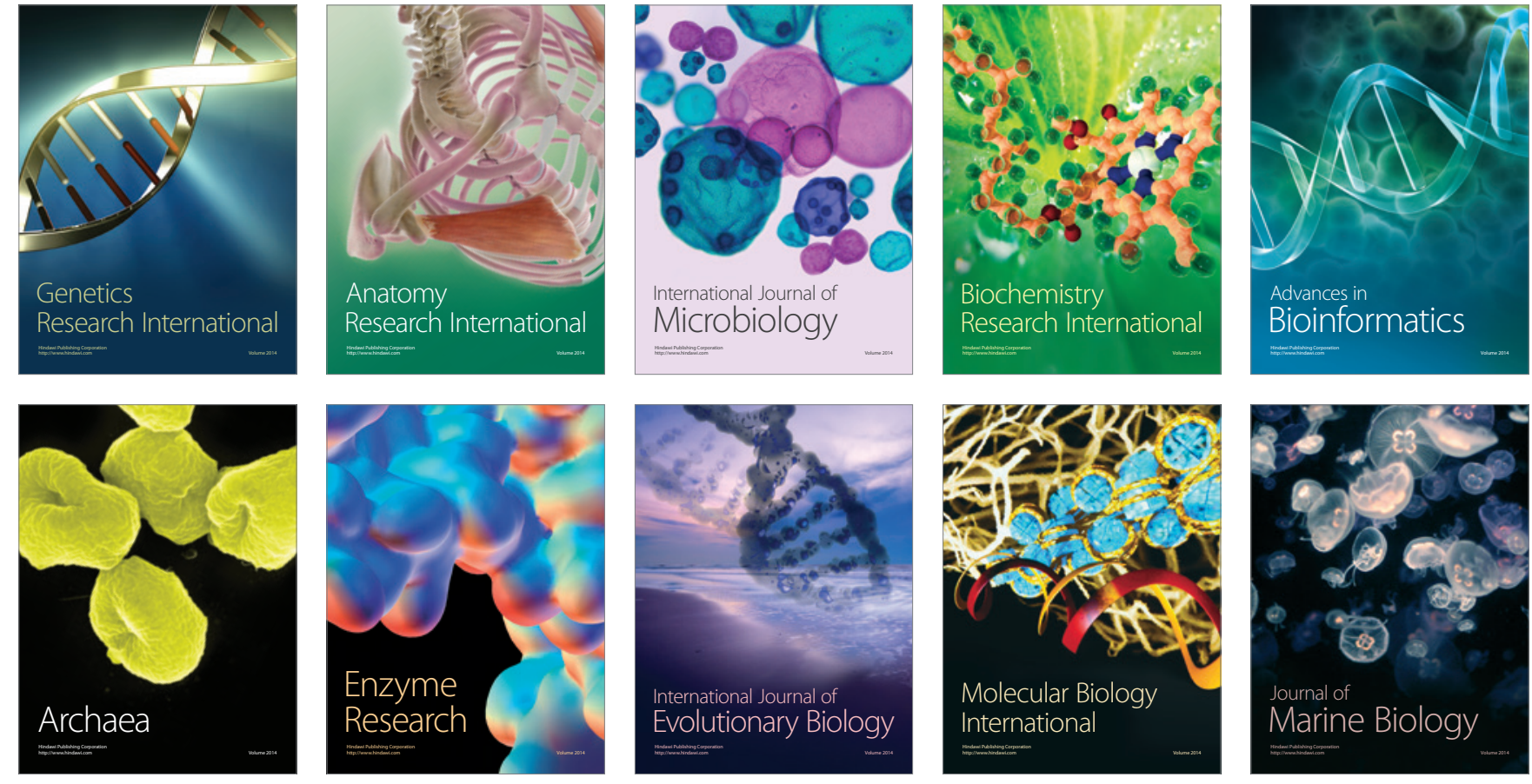